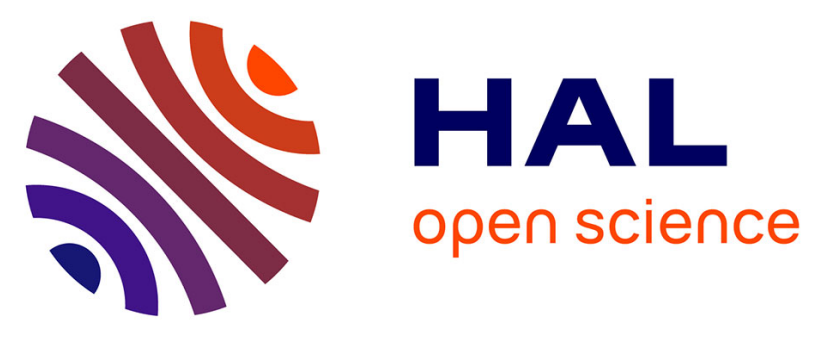

\title{
Sixty years from the first disease description, a novel badnavirus associated with chestnut mosaic disease
}

\author{
Armelle Marais, Sergio Murolo, Chantal Faure, Yoann Brans, Clement Larue, \\ François Maclot, Sébastien Massart, Michela Chiumenti, Angelantonio \\ Minafra, Gianfranco Romanazzi, et al.
}

\section{To cite this version:}

Armelle Marais, Sergio Murolo, Chantal Faure, Yoann Brans, Clement Larue, et al.. Sixty years from the first disease description, a novel badnavirus associated with chestnut mosaic disease. Phytopathology, 2021, 111 (6), pp.1051-1058. 10.1094/PHYTO-09-20-0420-R . hal-03036205

\section{HAL Id: hal-03036205 \\ https://hal.inrae.fr/hal-03036205}

Submitted on 6 Sep 2021

HAL is a multi-disciplinary open access archive for the deposit and dissemination of scientific research documents, whether they are published or not. The documents may come from teaching and research institutions in France or abroad, or from public or private research centers.
L'archive ouverte pluridisciplinaire HAL, est destinée au dépôt et à la diffusion de documents scientifiques de niveau recherche, publiés ou non, émanant des établissements d'enseignement et de recherche français ou étrangers, des laboratoires publics ou privés.

\section{(c)(1)}

Distributed under a Creative Commons Attribution| 4.0 International License 
1 Sixty years from the first disease description, a novel badnavirus associated with

2 chestnut mosaic disease

3

4 Armelle Marais*t ${ }^{1}$, Sergio Murolot ${ }^{2}$, Chantal Faure ${ }^{1}$, Yoann Brans ${ }^{3}$, Clément Larue ${ }^{4,5}$, François

5 Maclot $^{6}$, Sébastien Massart ${ }^{6}$, Michela Chiumenti $^{7}$, Angelantonio Minafra ${ }^{7}$, Gianfranco Romanazzi ${ }^{2}$,

6 Marie Lefebvre ${ }^{1}$, Teresa Barreneche ${ }^{1}$, Cécile Robin ${ }^{4}$, Rémy J. Petit ${ }^{4}$, Thierry Candresse ${ }^{1}$

7

$8 \quad{ }^{1}$ Univ. Bordeaux, INRAE, UMR BFP, Villenave d'Ornon, France

92 Department Agricultural, Food and Environmental Sciences, UNIVPM, Ancona, Italy

$10{ }^{3}$ Laboratoire de Virologie et de Biologie moléculaire, CTIFL, Prigonrieux, France

$11{ }^{4}$ Univ. Bordeaux, INRAE, UMR Biogeco, Cestas, France

${ }^{5}$ INVENIO, Maison Jeannette, Douville, France

${ }^{6}$ Plant Pathology Laboratory, TERRA-Gembloux Agro-BioTech, University of Liège, Belgium

${ }^{7}$ CNR Institute for Sustainable Plant Protection - Bari, Italy

* Corresponding author: A. Marais; Email: armelle.marais-colombel@inrae.fr

TAM and SM contributed equally to this work

Keywords: High throughput sequencing, Castanea sp., etiology, viral disease, Badnavirus,

\section{Caulimoviridae}

The nucleotide sequences reported here have been deposited in GenBank under the accession numbers MT261366, MT269853, MT270664-MT270682, and MT339503-MT339590. 
Armelle Marais

Phytopathology 2

Although the chestnut mosaic disease (ChMD) was described several decades ago, its etiology is still not elucidated. Here, using classical approaches in combination with high throughput sequencing (HTS) techniques, we identify a novel Badnavirus that is a strong etiological candidate for ChMD. Two disease sources from Italy and France were submitted to HTS-based viral indexing. Total RNAs were extracted, ribodepleted and sequenced on an Illumina NextSeq500 (2x150 or 2x 75 nt). In each source, we identified a single contig of about 7.2 kilobases that corresponds to a complete circular viral genome and shares homologies with various badnaviruses. The genomes of the two isolates have an average nucleotide identity of $90.5 \%$ with a typical badnaviral genome organization comprising three open reading frames. Phylogenetic analyses and sequence comparisons show that this virus is a novel species for which we propose the name Chestnut mosaic virus (ChMV). Using a newly developed molecular detection test, we systematically detected the virus in symptomatic graft-inoculated indicator plants (chestnut and American oak), as well in chestnut trees presenting typical ChMD symptoms in the field (100\% and $87 \%$ in France and Italy surveys, respectively). Datamining of publicly available chestnut SRA transcriptomic data allowed the reconstruction of two additional complete ChMV genomes from two Castanea mollissima sources from the USA, as well as ChMV detection in $C$. dentata from the USA. Preliminary epidemiological studies, performed in France and in Central Eastern Italy, showed that ChMV has a high incidence in some commercial orchards, with a low within-orchard genetic diversity. 
European chestnut (Castanea sativa Mill.) has a long-standing tradition of cultivation in many European countries. It is an important species, both economically as a source of timber and fruit and ecologically through the multiple ecosystemic services it provides. In Europe, chestnut covers about 2.5 million hectares, mainly concentrated in France, Italy, Spain, Portugal, Switzerland, the Balkan regions, and Southern England (Conedera et al. 2016). Chestnut (Castanea spp.) can be heavily affected by various pathogens. The most detrimental are caused by fungal-like organisms (Oomycetes) and fungi such as Phytophthora cambivora Petri and P. cinnamomic Rands., the agents of ink disease, or Cryphonectria parasitica, the causal agent of chestnut blight, which all provoke disorders that can lead to tree mortality (Prospero et al. 2012; Rigling and Prospero, 2018). In Italy, Gualaccini (1958) described a chestnut disease associated with viral symptoms (mosaic, shoots with asymmetric leaf blade deformation) which was again reported in Campania during the 80s, (Ragozzino and Lahoz 1986), and in the Marche region (central eastern Italy) in 2000 (Antonaroli and Perna; 2000). In France, the disease was first identified circa 1987 on cultivars of $C$. sativa $\times$ C. crenata hybrids from commercial orchards located in the south-west of the country. Desvignes (1999b) made a more detailed description of the symptoms, which are characterized by necrotic lesions in the bark and wood that turns into cankers, chlorotic lesions and yellow stripes on leaf veins and partial limb atrophy, and called this disease Chestnut Mosaic Disease (ChMD). This disease can heavily affect the production of both young and secular trees (Antonaroli and Perna, 2000). It has also been reported in Japan and Hungary (Shimada, 1962; Horvath et al. 1975). Even if its etiology has long remained unknown, researchers hypothesized that the causal agent of ChMD could be a virus, introduced in Europe between 1940 and 1960 when a number of C. crenata cultivars were imported from Japan for breeding purposes. Investigations in France and Italy established that the causal agent can be eliminated by thermotherapy, is aphid-transmissible, and is graft-transmissible to Castanea and Quercus species in which it may elicit symptoms (Desvignes 
Armelle Marais

Phytopathology 4

and Lecocq, 1995; Desvignes, 1999b; Vettraino et al. 2005). The susceptibility to the ChMD agent of Castanea species/cultivars has been evaluated in several studies (Desvignes, 1992; 1999b; Desvignes and Lecoq, 1995). Three categories of cultivars could thus be defined from tolerant to moderately and fully susceptible. Graft incompatibility was also observed when cultivars of different susceptibilities are assembled by grafting. Most of the $C$. sativa cultivars and hybrids are tolerant to ChMD, although some well-known French hybrids like 'Maraval' (Ca 74) are fully susceptible, and used for indexing purposes to detect the ChMD agent in tolerant cultivars (Desvignes and Lecoq, 1995).

In the last decade, a number of studies have highlighted the potential of non-targeted molecular diagnostics based on high-throughput sequencing (HTS) to elucidate the etiology of viral plant diseases and to provide viral sequence data from which rapid diagnostic molecular assays can be developed (Martin et al. 2016; Villamor et al. 2019). Since 2009, HTS combined with bioinformatics have been used for the discovery, characterization, and de novo assembly of the genome of known and novel plant viruses and viroids (Rott et al. 2017; Kreuze et al. 2009). This has accelerated the application of HTS technologies in the field diagnostic of diseases (Massart et al. 2014), and in quarantine regulations (Martin et al. 2016; Massart et al. 2017).

Badnaviruses are plant pararetroviruses belonging to the family Caulimoviridae that have emerged as serious pathogens causing severe yield losses in a wide range of economically important crops all over the world (Bhat et al. 2016). The genome of badnaviruses is composed of a noncovalently closed, circular double-stranded DNA (ranging from 7.2 to $9.2 \mathrm{kbp}$ ) and is encapsidated in bacilliform virions. This genome typically harbors three open reading frames (ORFs) encoding, respectively, a protein of unknown function, the virion-associated protein (VAP), and a polyprotein containing functional and structural domains [movement protein (MP), coat protein (CP), aspartic protease (AP), reverse-transcriptase (RT) and RNase H)] (Hohn and Rothnie, 2013; Bhat et al. 2016). 
Badnaviruses can also be present as integrated sequences in some host plant genomes (endogenous badnaviruses) (Staginnus et al. 2009; Bhat et al. 2016). The contribution of these integrated sequences to host and virus evolution is still poorly understood (Geering et al. 2014).

Given the very limited knowledge on the etiology of ChMD, and based on previously published studies (Desvignes, 1992; 1999a, 1999b; Desvignes and Lecoq, 1995; Desvignes and Cornaggia, 1996), we investigated the hypothesis that a virus might be involved in this disease. Combining HTSbased viral indexing and classical approaches, we report here the complete genome sequence of a novel badnavirus species for which the name Chestnut mosaic virus (ChMV) is proposed. We further show that there is a strict correlation between the presence of the virus and the appearance of typical ChMD symptoms in various graft-inoculated indicator plants. Preliminary epidemiological studies carried out in Italy and in France reveal that the virus can have high incidence in some orchards, and, as expected, can be associated with symptomatic or asymptomatic infections.

\section{MATERIALS AND METHODS}

Plant samples and virus isolates. Virus isolates included in this study are listed in Supplementary Table S1. Isolate LC1224H is originated from a red oak (Quercus rubra) artificially inoculated in 1992 with a chestnut mosaic source from a hybrid Castanea sativa $\times$ Castanea crenata included in a French breeding program. Leaves of grafted oaks displayed typical symptoms characterized by chlorotic mottle, yellow veins, and mosaic (Desvignes and Lecoq 1995) (Figure 1A). Isolate FRIC1224A was derived from the same source, and is the result of a back-inoculation by grafting of LC1224H to the natural chestnut hybrid Maraval (Ca 74; C. crenata $\times$ C. sativa) indicator (Desvignes et al. 1992). Isolate LC1224F originated from a Maraval indicator inoculated by aphid transmission from an initial ChMD source in a C. crenata $\times$ C. sativa French hybrid (Desvignes and Cornaggia, 1996). The LCA552 and LCA584 isolates were collected from C. sativa trees in France in 2009 and 
Armelle Marais

Phytopathology 6

2018, while the T32018 disease source was isolated from a French hybrid C. crenata $\times$ C. sativa in

2018. All of these isolates have been held and propagated on 'Maraval' indicator plants at the CTIFL virology laboratory (Lanxade, France).

In the framework of a survey carried out in Italian chestnut orchards to monitor chestnut blight (Acquasanta Terme (AP), locality Umito, Italy) (Murolo et al. 2018), typical leaf symptoms of ChMD were recorded in 2016. Six symptomatic plants were collected, pooled (10 -15 symptomatic shoots) and included in the HTS analysis (ITumito39 source).

In order to evaluate the incidence of ChMV, chestnut trees from INRAE chestnut biological resource center (https://www6.bordeaux-aquitaine.inrae.fr/biogeco/Ressources) were sampled. This orchard is located on the Villenave d'Ornon INRAE center (France) with trees distributed in three plots (A, E, or Port, Table S1). A total of 43 C. sativa, 14 C. mollissima, six C. crenata and 32 hybrid chestnut trees were sampled, corresponding to a total of 38 symptomatic trees with typical ChMD symptoms, 47 asymptomatic trees, and 10 trees with dubious or atypical symptoms. In addition, in the Central eastern Italy Marche region, leaves from 60 symptomatic and from 10 asymptomatic grafted $C$. sativa $\mathrm{cv}$. Marrone trees of different ages were collected in a commercial chestnut orchard (Plot I, Table S1).

Isolates FRIc1224A and ITumito39 were used for the HTS analysis, whereas all other samples were included either in the incidence analysis or in the causal relationship analysis (Table S1).

Total RNA extraction and RNA-Seq analysis. Symptomatic leaves from a 'Maraval' indicator (FRIc1224A) were collected and used to extract total RNAs according to the protocol described by Reid et al. (2006). For the Italian material, total RNAs were extracted from symptomatic leaves according to the protocol described by Gambino et al. (2008). Total RNAs were then submitted to a DNAse treatment following the manufacturer's recommendations (Fisher Scientific, Illkirch, France). Ribosomal RNAs were removed using a RiboMinus Plant Kit for RNA-Seq (Invitrogen, Fisher 
Scientific, Illkirch, France) before cDNA library synthesis with the Illumina TruSeq Stranded RNA library Prep kit (Illumina, Inc., San Diego, CA) and sequenced on an Illumina NextSeq500 (2x150 nt or 2x75 nt) in a multiplexed format (GIGA-Genomics facility, Université de Liège, Belgium).

Bioinformatic analysis. Primary quality analyses were performed using Geneious Prime 2019.2.1 Software (https://www.geneious.com). De novo assemblies of quality filtered reads were performed using Velvet (Zerbino and Birney, 2008), Geneious R 11 (https://www.geneious.com), and Spades (Bankevich et al. 2012), or using the CLC genomics workbench 8.0 http://www.clcbio.com). Contigs were annotated by BlastN and BlastX comparisons with nucleotide and non-redundant protein GenBank databases, respectively. Blast results were screened using evalue thresholds of $10^{-6}$ and $10^{-4}$ for BlastN and BlastX, respectively. Publicly available chestnut RNASeq transcriptomic data were retrieved from the NCBI Sequence Read Archive (SRA) and downloaded reads were mapped against the sequence of the FRIc1224A isolate using CLC Genomics Workbench 11.0. When needed, de novo assembly and contig annotations were also performed as described above.

\section{Total DNA extraction and PCR confirmation of genome completeness and circularity. In order}

to verify both the completeness of the assembled genome sequences and genome circularity, pairs of specific outward-facing primers were designed for each isolate (Ch-Bad-6976F/ Ch-Bad-252R for the isolate FRIc1224A and Bad-Ch-6481F/Bad-Ch-325R for the isolate ITumito39, Table S2). Leaf tissues $(0.5 \mathrm{~g}$ ) were pulverized in liquid nitrogen and total DNA was extracted in CTAB buffer ( $2 \%$ cetyl trimethylammonium bromide, $100 \mathrm{mM}$ Tris- $\mathrm{HCl}, 1.4 \mathrm{M} \mathrm{NaCl}, 20 \mathrm{mM}$ EDTA), adding 3\% polyvinyl pyrrolidone 40 , and $0.5 \%$ sodium metabisulfite (Doyle and Doyle, 1990). Finally, the DNA pellets were resuspended in $50 \mu \mathrm{l}$ sterile water. PCRs were performed in a $50 \mu$ l reaction volume containing $10 \mathrm{mM}$ Tris- $\mathrm{HCl}(\mathrm{pH} 8.5), 2 \mathrm{mM} \mathrm{MgCl}$, $50 \mathrm{mM} \mathrm{KCl}, 0.2 \mathrm{mM}$ dNTPs, forward and reverse primers at $1 \mu \mathrm{M}$ each, and $1.25 \mathrm{U}$ of Dream Taq (ThermoFisher) using $50 \mathrm{ng}$ of the template. After an 
Armelle Marais

Phytopathology 8

166 initial denaturation step at $95^{\circ} \mathrm{C}$ for 4 min, 40 or 35 cycles, respectively, were set at $94^{\circ} \mathrm{C}$ for $30 \mathrm{sec}$,

167

168

169

170

171

172

173

174

175

176

177

$60^{\circ} \mathrm{C}(\mathrm{Ch}-\mathrm{Bad}-6976 \mathrm{~F} / \mathrm{Ch}-\mathrm{Bad}-252 \mathrm{R})$ or $55^{\circ} \mathrm{C}$ (Bad-Ch-6481F/325R) for $30 \mathrm{sec}$, and $72^{\circ} \mathrm{C}$ for $90 \mathrm{sec}$, followed by a final extension step of $10 \mathrm{~min}$ at $72^{\circ} \mathrm{C}$. PCR amplification products were sequenced on both strands (GATC, Eurofins, Ebersberg, Germany).

ChMV molecular detection and variant analysis by PCR. For the molecular detection of ChMV, two sets of primers were designed in conserved regions of ORF3 designed using the sequences of isolates FRIc1224A and ITumito39. One primer pair (Ch-Bad-1466F/Ch-Bad-1800R, Table S2) allows the amplification of a genomic region (335 nt) in the MP domain (Figure 2), whereas the second pair (Ch-Bad-5860F/Ch-Bad-6109R, Table S2) amplifies a 232-nt fragment in the RH domain (Figure 2). An aliquot of $25 \mathrm{ng}$ of total DNA was used for the PCR assays in a $50 \mu$ l volume containing $10 \mathrm{mM}$ Tris- $\mathrm{HCl}(\mathrm{pH} 8.5), 2 \mathrm{mM} \mathrm{MgCl} 2,50 \mathrm{mM} \mathrm{KCl}, 0.2 \mathrm{mM}$ dNTPs, forward and reverse primers at $1 \mu \mathrm{M}$ each, and either $1.25 \mathrm{U}$ of DreamTaq or $1 \mathrm{U}$ of GoTaq. After an initial denaturation step at $95^{\circ} \mathrm{C}$ for 4 min, 35 cycles were set at $94^{\circ} \mathrm{C}$ for $30 \mathrm{sec}, 56^{\circ} \mathrm{C}$ for $30 \mathrm{sec}$, and $72^{\circ} \mathrm{C}$ for $90 \mathrm{sec}$, followed by a final extension step of $10 \mathrm{~min}$ at $72^{\circ} \mathrm{C}$. Amplicons were analyzed by electrophoresis on $1.5 \%$ agarose gel and were directly sequenced on both strands (GATC).

Possible phytoplasma infection was evaluated using primer pair P1/P7 (Deng and Hiruki. 1991; Smart et al. 1996) and, in nested PCR, primers R16F2n/R2 (Gundersen and Lee 1996).

Sequence and phylogenetic analyses. The full-length genomes were analyzed by ORF Finder (http://www.ncbi.nlm.nih.gov/projects/gorf/) to identify putative ORFs in the viral genome. Deduced amino acid (aa) sequences were analyzed for conserved protein domains gathered in Conserved Domains Database (CDD) (http://www.ncbi.nlm.nih.gov/structure/cdd.shtml) and theoretical molecular weights were calculated using ExPASy (http://web.expasy.org/compute pi/). Multiple alignments of nucleotide (nt) or amino acid (aa) sequences were performed using the ClustalW program (Thompson et al. 1994) implemented in MEGA version 7.0 (Kumar et al. 2016). 
190 Genetic distances ( $p$-distances using strict nt or aa identity) were calculated using MEGA 7.0. 191 Phylogenetic trees were reconstructed using the neighbor-joining method implemented in MEGA 1927.0 and robustness of nodes was assessed from 1,000 bootstrap resamplings.

193

\section{RESULTS}

Determination of the complete genome sequence of a novel badnavirus from two chestnut disease sources. Two ChMD sources were included in the HTS analysis. The French source (FRIc1224A) showed typical ChMD symptoms, with leaf deformation, yellow veins and chlorotic diffuse mottling (Figure 1B) and the Italian source (ITumito39) is a mixture of six plants showing intensive vein banding and leaf blade deformation (Figure 1C). High-throughput sequencing of ribodepleted RNAs extracted from the sources FRIc1224A and ITumito39 yielded a total of $10,737,052$ reads and 4,135,330 reads, respectively. De novo assembly and Blast annotation allowed for the identification of a single long contig with significant homology with badnaviruses. These contigs were respectively 7,264 and 7,214 bp long and showed short terminal redundancies, consistent with the structure of the long RNA transcript involved in the replication of badnaviruses (Teycheney et al. 2020) and suggesting they represented the full coverage of a circular badnaviral genome. A total of 39,657 reads were integrated in the FRIc1224A contig, representing $0.37 \%$ of total reads, with a mean coverage depth of $795 \mathrm{X}$, whereas 611 reads $(0.015 \%$ of total reads) were integrated in the ITumito39 contig, with a mean coverage depth of $14.4 \mathrm{X}$. The circularity and completion of the DNA genome sequence of each isolate were validated by a PCR on purified DNA extracted from the host plants and using specific outward-facing primers designed from the contig sequences. The respective $436 \mathrm{nt}$ - and 1,007 nt fragments were amplified and sequenced, confirming DNA genome completeness and circularity (data not shown). The assembled sequences 
Armelle Marais

Phytopathology 10

212 have been deposited in GenBank under accession numbers MT269853 and MT261366, respectively.

213 No other plant virus was detected in the two datasets during the Blast annotation of contigs.

\section{Genome organization of chestnut mosaic virus and determination of its phylogenetic}

relationships. The badnaviral genomes characterized independently from the French and Italian

ChMD sources are respectively 7,160 bp and 7,161 bp long, within the range of badnavirus genome

sizes (Teycheney et al. 2020). The genomic organization is the same for both isolates, comprising

three open reading frames (ORFs) encoded on the positive strand (Figure 2), and is typical for badnaviruses (Teycheney et al. 2020). The ORF1 (nt 245-751, numbering according to the isolate FRIc1224A sequence) encodes a protein of 169 aa (19.8 kDa), the ORF2 (nt 751-1161) encodes a

137-aa protein (15 kDa), and the third ORF (nt 1,163-6,721) encodes a polyprotein of 1,853 aa ( 211.7

kDa) with five conserved protein domains (Figure 2): a viral movement protein (MP, cl03100), a zincbinding motif (ZnF, pfam00098), a retroviral aspartyl protease domain (RVP, pfam00077), a reverse transcriptase domain (RT, cd01647) and a ribonuclease $\mathrm{H}$ domain (RH, cl14782). The two "Cys"

motives ( $\mathrm{C}-\mathrm{X}_{2}-\mathrm{C}-\mathrm{X}_{4}-\mathrm{H}-\mathrm{X}_{4}-\mathrm{C}$, and $\left.\mathrm{C}-\mathrm{X}_{2}-\mathrm{C}-\mathrm{X}_{11}-\mathrm{C}-\mathrm{X}_{2}-\mathrm{C}-\mathrm{X}_{4}-\mathrm{C}-\mathrm{X}_{2}-\mathrm{C}\right)$ usually found in the coat protein of badnaviruses (Bath et al. 2016) were also detected in the ORF3-deduced protein, between aa positions $777-790$ and $902-928$.

Both isolates are closely related, with an overall $90.5 \% \mathrm{nt}$ identity. The three indels observed between the two sequences are located in the intergenic region, the isolate ITumito39 ended up being one nucleotide longer. The three ORFs have the same sizes, are strictly colinear and the encoded proteins share respectively 95.2\% (ORF1), 95.5\% (ORF2) and 94.8\% (ORF3) aa identity.

To characterize the phylogenetic relationships and taxonomic position of the chestnut badnavirus, a phylogenetic tree was reconstructed using an alignment of full genome nucleotide sequences of Badnavirus genus members, with the rice tungro bacilliform virus used as an outgroup 
236 237

vein banding virus (GVBV), rubus yellow net virus (RYNV), grapevine vein clearing virus (GVCV), birch leafroll-associated virus (BLRaV), wisteria badnavirus 1 (WBV1), and pagoda yellow mosaicassociated virus (PYMaV) (Figure 3). Nevertheless, they are clearly distant from all of these species, defining a novel branch, supported by a $99 \%$ bootstrap value (Figure 3). Tree topology was similar when using an alignment of representative badnaviral ORF3 protein sequences (Figure S1). To confirm these analyses, pairwise comparisons of genome sequences showed that the isolate FRIc1224A has only weak identity levels with representative members of the genus Badnavirus, comprised between $42.1 \%$ nt identity (sugarcane bacilliform IM virus; $42.5 \%$ for the isolate ITumito39) and 50.9\% (WBV1; 50.8\% for the isolate ITumito39). The same tendency is observed when considering the genome proteins. The ORF1-encoded protein shows only weak homology with the corresponding proteins of WBV1 (27.8\% aa identity) and PYMAV (26.1\% aa identity), and the ORF2-encoded protein shares only $33.1 \%$ aa identity with the corresponding protein of the most closely related virus, WBV1. The polyprotein encoded by ORF3 shares $49.5 \%$ aa identity with the corresponding protein of the closest relative, PYMAV. Using the ORF3 region (RT and RH domain) used for taxonomical discrimination in the family Caulimoviridae (Teycheney et al. 2020), the FRIc1224A isolate shows between 64\% (with GVBV) and 68.4\% (with BLRaV) nt identity (Table 1), which is below the $80 \%$ nt identity value used as the species demarcation threshold in the family. Therefore, this virus represents a novel species in the family Caulimoviridae, for which we propose the name Chestnut mosaic virus (ChMV). In the same taxonomically informative region, the isolates FRIC1224A and ITumito39 share $91.9 \%$ nt identity ( $97.8 \%$ aa identity), indicating that they belong to the same viral species (Table 1).

Identification of ChMV in publicly available chestnut HTS data. The datamining of chestnut HTS data from various chestnut sources publicly available at GenBank [EST sequences, whole genome assembly, RNA-Seq and Genotyping-by-sequencing (GBS) reads available as Sequence Read 
Armelle Marais

Phytopathology 12

260

261

Archives (SRA)] allowed the identification of ChMV in several of those datasets (Table S3). In particular, two complete genomes were obtained from datasets involving C. mollissima cv. Vanuxem in the USA, one from the whole genome assembly (JRKL01079565) and the other by de novo assembly of RNA-Seq data (SRX4015368) with $99.2 \%$ and $97.4 \%$ nt identity, respectively, with the FRIC1224A isolate over the whole genome (Figure 4). In addition, partial ChMV genome assemblies of $>3 \mathrm{kbp}$ could be obtained from a range of other datasets generated in the USA or in China from C. mollissima (Table S3), all of which showed significant relatedness with the FRIc1224A sequence as shown by a phylogenetic tree reconstructed using nucleotide alignments of concatenated ChMV sequences retrieved from the various datasets (Figure 4). In addition, partial ChMV genomes could also be reconstructed from two datasets obtained from $C$. dentata in the USA. Interestingly, one of these two $C$. dentata isolate sequences shows closest relationship with ITumito39 sequence (Figure 4) with only $89.2 \%$ nt identity with the isolate FRIc1224A as compared to $93.9 \%$ nt identity with ITumito39. The second isolate of $C$. dentata appears to be equally related to the FRIC1224A and ITumito39 isolates, with $90.9 \%$ and $90.6 \%$ nt identity, respectively.

Incidence and genetic variability of ChMV in France and Italy. The incidence and genetic variability of ChMV were investigated by analyzing two genomic regions of ORF3, one 335-nt long located in the MP domain amplified using primer pair Ch-Bad-1466F/Ch-Bad-1800R and the other 232-nt long in the RNase $\mathrm{H}$ domain and amplified with primer pair Ch-Bad-5860F/Ch-Bad-6109R (Table S2, and Figure 2). The two primer pairs were designed to be able to detect both isolates FRIc1224A and ITumito39. In Italy, a total of 70 C. sativa cv Marrone samples were collected in the same location, while in France, 95 chestnut accessions belonging to three different Castanea species or hybrids were sampled in three plots (A, Port, E). Both symptomatic and asymptomatic samples were collected, as well as some samples with atypical or dubious symptoms. Globally, ChMV was frequent in the surveyed plots, with $57 / 70$ (81.5\%) infected C. sativa samples in Italy and 65/95 trees 
$284(68 \%)$ in France (Table 2). In the Italian orchard, half of the asymptomatic trees were found to be infected by ChMV, compared to $87 \%$ of the symptomatic ones (Table 2). None of the analyzed samples were found positive using a phytoplasma-specific PCR assay. In the French collection, the virus was detected in $100 \%(38 / 38)$ of the trees showing typical ChMD symptoms, and in $49 \%$ $(23 / 47)$ of the asymptomatic trees, including two trees that were symptomless but showed strong symptoms on rootstock off-shoots (Figure S2). ChMV was also detected in four out of the 10 trees showing atypical/doubtful symptoms.

The genetic variability of ChMV was evaluated by analyzing the sequences of the two PCR amplicons generated for the incidence survey. Considering the relative homogeneity of the origin of the Italian samples, the number of samples included in this analysis was limited to 13 (four from asymptomatic trees, and nine symptomatic ones) (Table S1). In total, the final dataset consisted in 53 isolates for which the sequence of the two genomic regions were available ( 49 from the incidence survey and four from independent ChMD sources held in collection at CTIFL, see below). As illustrated by the unrooted neighbor-joining tree reconstructed from the alignments of RT-RnaseH domain nucleotide sequences (Figure S3A), ChMV diversity is structured into two clusters, defined by the geographical origin of the samples (Italy and France). The sequences determined from the four independent French disease sources (FRIc1224A, T30218, LCA552, LCA584) belong to the same «French» cluster. Overall, the level of genetic diversity is very low in this genomic region, with an average pairwise nt divergence (diversity) of $2.2 \%+/-0.5 \%$. This value is even lower when considering the intra-group diversity, as $0.2 \%+/-0.1 \%$ within the French cluster and $0.1 \%+/-0.1 \%$ within the Italian ones. In contrast, the inter-group diversity reaches $6.3 \%+/-1.5 \%$, confirming the existence of two geographical clusters. The same trends are observed when analyzing the genomic region located in the MP domain (Figure S3B). The same geographical clustering could be observed, 
Armelle Marais

Phytopathology 14 cluster (Figure S3B). Another French isolate, 20971-E remains isolated and does not fit in either group. The average nt divergence in this region is slightly higher than in the RT-RNaseH region, (5.8\% $+/-0.7 \%)$, and the inter-group diversity reaches a value of $13.4 \%+/-1.8 \%$, as compared to the $6.3 \%$ value for the other region.

\section{DISCUSSION}

Since the seminal work of Desvignes and collaborators in the 1990s, it has been acknowledged that the agent responsible for ChMD is most likely a thermosensitive, graft-transmissible virus that can be transmitted experimentally and probably naturally by the aphid Myzocallis castanicola Desvignes, 1992; 1999a; 1999b; Desvignes and Lecoq, 1995; Desvignes and Cornaggia, 1996). Depending on the chestnut genotype, this infection can either be asymptomatic or can result in the expression of severe and conspicuous ChMD symptoms. In chestnut orchards in the Marche region (Italy), both young and mature plants were shown to be affected, significantly decreasing chestnut production. Symptoms have also been observed in some Quercus species following experimental graft inoculation. To date, however, the causal agent remains to be identified.

Here, by using HTS-based viral indexing, we were able to identify and characterize, in two independent ChMD sources, two isolates of the same novel virus. Phylogenetic and sequence analyses showed that this virus belongs to the genus Badnavirus, in the family Caulimoviridae, and could be considered as a new species, for which the name Chestnut mosaic virus (ChMV) is proposed. Interestingly, this new virus clusters with a group of badnaviruses that includes RYNV, GVBaV, and GVCV.

There is unambiguous evidence that ChMV as reported here is an episomal virus. It was detected in graft-inoculated indicators, and not in non-inoculated control plants of the same variety, demonstrating its graft-transmissibility, a property of episomal viruses. This line of evidence is further reinforced by the detection of ChMV in symptomatic, graft-inoculated indicator Quercus 

plants and, again, not in the corresponding control plants. In parallel, the HTS detection of ChMV from DNAse-treated RNAs, the failure to detect ChMV in a range of the surveyed chestnut trees and the sequence diversity identified in ChMV all rule out a scenario in which an endogenous ChMV genome, integrated in the chestnut genome could be responsible for the HTS and PCR results reported here. There was in fact no indication of ChMV in the chestnut genome assembly (JRKL01079565) since no integration borders could be identified and a single contig, representing a complete unintegrated viral genome transcript, was identified. Integration of ChMV as an endogenous viral element (EVE, Bhat et al. 2016) therefore does not appear to be a general genomic feature of chestnut.

According to the simplified hierarchical approach proposed by Fox (2020) for assessing causal relationships in plant virology, ChMV appears as a good candidate, if not as the causative agent of ChMD. There are several arguments and experimental evidence supporting this idea. Following HTS analyses, ChMV was the sole virus detected in the French source FRlc1224A, coming from a ChMD source initially involving a $C$. sativa $\times$. crenata hybrid. It was also the sole virus detected in the Italian ChMD source analyzed by HTS. Using molecular detection tests developed in this work, the virus was consistently found in other symptomatic accessions derived from the same diseased source (LC1224H, a Q. rubra artificially inoculated and LC1224F, an indicator plant inoculated by aphid transmission; Figure 5). In addition, three other independent chestnut sources shown by biological indexing on the 'Maraval' indicator to be affected by ChMD were found to be infected by ChMV (LCA552, LCA584 and T32018 in Figure 5). There is therefore a correlation between the appearance of ChMD symptoms and the presence of ChMV in the graft-inoculated indicators, supporting the hypothesis of a causal relationship between ChMV infection and ChMD. In total, five independent ChMD sources collected between 1990 and 2018 in two countries (Italy and France) 
Armelle Marais

Phytopathology 16

355

356

were ChMV positive, satisfying the Bradford-Hill's experimental and consistency criteria (Bradford Hill, 1965; Fox, 2020).

Preliminary studies indicate that ChMV is highly prevalent in the analyzed orchards in France and Italy, confirming the earlier results of Desvignes (1999a). In parallel, the identification of ChMV sequences in publicly available HTS data provides a strong indication of the presence of ChMV in $C$. mollissima in the USA and in China and in C. dentata in the USA. In the surveys, ChMV was not systematically associated with symptomatic infections, although its frequency was systematically higher in symptomatic plants. This result was expected since previous grafting experiments had demonstrated that not all chestnut varieties/species are susceptible to ChMD and develop symptomatic infections (Desvignes and Lecoq, 1995; Desvignes, 1992; 1999b). Biological indexing on the susceptible 'Maraval' indicator has in particular identified latent ChMV infections in many symptomless C. sativa varieties or C. sativa x C crenata hybrids (Desvignes and Lecoq, 1995; Desvignes, 1992; 1999b). On the other hand, all surveyed symptomatic plants in France were found to harbor the virus, while it was detected in $52 / 60(87 \%)$ of tested symptomatic Italian trees. The failure to detect ChMV in eight symptomatic Italian trees might reflect sequence variability and an incomplete inclusiveness of the PCR primers used or low or uneven virus accumulation. Indeed, using biological indexing, Desvignes et al. have previously found an uneven distribution of the ChMD agent in infected trees leading to a failure to detect it in parts of some infected trees (Desvignes and Lecoq, 1995; Desvignes et al. 1999b).

Taken together, and even though Koch's postulates were not fully verified, the experiments reported here make a very strong case for a role of ChMV as the causal agent of the chestnut mosaic disease. The low ChMV diversity observed in France and Italy are consistent with the scenario of its recent introduction in Europe (Desvignes and Lecoq, 1995), while the genetic separation of the Italian and French clusters is suggestive of separate introduction events. These results and the 
379 associated development of molecular tools for the detection of ChMV will help speed up the 380 selection of virus-free mother plants and mitigate the virus spread in new chestnut orchards and 381 layerings. However, many questions remain regarding the variability of symptom intensity in 382 relationship to cultivar susceptibility, ChMV-induced graft incompatibility, the impact of 383 pedoclimatic conditions and of synergic and competitive interferences with other chestnut 384 pathogens, and silvicultural management.

\section{ACKNOWLEDGMENTS}

The authors thank the INRAE Vine Experimental Unit of Bordeaux (UEVB) and X. Capdevielle for

taking care of chestnut orchards. We would like to thank Ascenzio Santini (Azienda Agricola Laga

Nord, Umito, Aquasanta Terme, Italy) for the essential support during the phytosanitary monitoring

in chestnut orchards. Thanks to D. Cornaggia and P. Gentit for the information provided on the past

work of CTIFL, for the characterization of the symptoms of the disease on biological indicators and

the conservation of the isolates. Thanks to Eden Darnige for proofreading the manuscript. Part of

this work was based upon COST Action FA1407 (DIVAS), supported by COST (European Cooperation in Science and Technology).

\section{LITERATURE CITED}

Antonaroli, R., and Perna, M.R. 2000. Una fitopatia ad eziologia ancora incerta: il giallume dl castagno in Emilia Romagna e nelle Marche. Sherwood 6:43-46.

Bankevich, A., Nurk, S., Antipov, D., Gurevich, A. A., Dvorkin, M., Kulikov, A. S., Lesin, V. M., 400 Nikolenko, S. I., Pham, S., Prjibelski, A. D., Pyshkin, A. V., Sirotkin, A. V., Vyahhi, N., Tesler, G., 401 Alekseyev, M. A., and Pevzner, P. A. 2012. SPAdes: a new genome assembly algorithm and its 402 applications to single-cell sequencing. J. Comput. Biol. 9:455-477. 
Armelle Marais

Phytopathology 18

403 Bhat, A. I., Hohn, T., and Selvarajan, R. 2016. Badnaviruses: the current global scenario. Viruses $404 \quad$ 8:177; doi:10.3390/v8060177.

405 Bradford Hill, A. 1965. The environment and disease: association or causation? Proc. R. Soc. Med. $406 \quad 58: 295-300$.

407 Conedera, M., Tinner, W., Krebs, P., de Rigo, D., and Caudullo, G. 2016. Castanea sativa in Europe: 408 distribution, habitat, usage and threats. Pages 78-79. in: European Atlas of Forest Tree Species. 409 J. San-Miguel-Ayanz, D. de Rigo, G. Caudullo, T. Houston Durrant, A. Mauri eds.

410 Deng, S. and Hiruki, C. 1991. Amplification of 16S rRNA genes from culturable and non-culturable 411 mollicutes. J. Microbiol. Meth. 14:53-61.

412 Desvignes, J. C. 1992. Characterization of the chestnut mosaic. Acta Hortic. 309:353-358.

413 Desvignes, J. C., and Lecocq, G. 1995. New knowledges on the chestnut mosaic virus disease. Acta $414 \quad$ Hortic. 386:578-584.

415 Desvignes, J. C., and Cornaggia, D. 1996. Mosaïque du chataignier: Transmission par le puceron $416 \quad$ Myzocallis castanicola. Phytoma 481:39-41.

417 Desvignes, J. C. 1999a. Mosaïque du chataignier. Pages 179-181. in: Maladies à virus des arbres $418 \quad$ fruitiers. Ctifl Ed. France

419 Desvignes, J. C. 1999b. Sweet chestnut incompatibility and mosaics caused by the chestnut mosaic 420 virus (ChMV). Acta Hortic. 494:451-454.

421 Doyle, J. J., and Doyle, J. L. 1990. Isolation of plant DNA from fresh tissue. Focus 12:13-15.

422 Fox, A. 2020. Reconsidering causal association in plant virology. Plant Pathol. doi: $423 \quad 10.1111 /$ ppa.13199

424 Gambino, G., Perrone, I., and Gribaudo, I. 2008. A rapid and effective method for RNA extraction 425 from different tissues of grapevine and other woody plants. Phytochem. Anal. 19:520-525. 
Geering, A. D. W., Maumus, F., Copetti, D., Choisne, N., Zwickl, D. J., Zytnicki, M., McTaggart, A. R., Scalabrin, S., Vezzulli, S., Wing, R. A., Quesneville, H. and Teycheney, P. Y 2014. Endogenous florendoviruses are major components of plant genomes and hallmarks of virus evolution. Nat. Comm. 5:5269

Gualaccini, G. 1958. Una virosi nuova del castagno. Boll. Staz Patol. Veg. Roma, 16:67-75.

Gundersen, D. E. and Lee, I. M. 1996. Ultrasensitive detection of phytoplasmas by nested-PCR assays using two universal primer pairs. Phytopathol. Mediterr. 35:144-151.

Hohn, T., and Rothnie, H. 2013. Plant pararetroviruses: replication and expression. Curr. Opin. Virol. $3: 621-628$.

Horvath, J., Ecke, I., Gal, T., and Dezcery, M. 1975. Demonstration of virus-like particles in sweet chestnut and oak with leaf deformations in Hungary. Z. Pflkrankh. Pfsdrntz. 82:498-502.

Kreuze, J. F., Perez, A., Untiveros, M., Quispe, D., Fuentes, S., and Barker, I. 2009. Complete viral genome sequence and discovery of novel viruses by deep sequencing of small RNAs: A generic method for diagnosis, discovery and sequencing of viruses. Virology 388:1-7.

Kumar, S., Stecher, G., and Tamura, K. 2016. MEGA 7: Molecular Evolutionary Genetics Analysis version 7 for bigger datasets. Mol. Biol. Evol. 33:1870-1874.

Martin, R. R., Constable, F., and Tzanetakis, I. E. 2016. Quarantine regulations and the impact of modern detection methods. Annu. Rev. Phytopathol. 54:189-205.

Massart, S., Olmos, A., Jijakli, H., and Candresse, T. 2014. Current impact and future directions of high throughput sequencing in plant virus diagnostics. Virus Res. 188:90-96.

Massart, S., Candresse, T. Gil, J., Lacomme, C., Predajna, L., Ravnikar, M., Reynard, J. S., Rumbou, A., Saldarelli, P., Škorić, D., Vainio, E. J., Valkonen, J. P. T., Vanderschuren, H., Varveri, C., and Wetzel, T. 2017. A framework for the evaluation of biosecurity, commercial, regulatory, and scientific 
Armelle Marais

Phytopathology 20

449

450

451

452

453

454

455

456

457

458

459

460

461

462

463

464

465

466

467

468

469

470

471

472

impacts of plant viruses and viroids identified by NGS technologies. Front. Microbiol. 8:45. doi: 10.3389/fmicb.2017.00045

Murolo, S., De Miccolis Angelini, R. M., Faretra F., and Romanazzi, G. 2018. Phenotypic and molecular investigations on hypovirulent Cryphonectria parasitica in Italy. Plant Dis. 102:540545.

Prospero, S., Vannini, A., and Vettraino, A. M. 2012. Phytophthora on Castanea sativa Mill. (sweet chestnut). JKI Data Sheets 6, DOI 10.5073/jkidspdd.2012.006

Ragozzino, A., and Lahoz, E. 1986. Una malattia virus-simile del castagno in provincia di Avellino. Giornate di studio sul castagno. Soc. Orti. Italiana 307-311.

Reid, K. E, Olsson, N., Schlosser, J., Peng, F., and Lund, S. T. 2006. An optimized grapevine RNA isolation procedure and statistical determination of reference genes for real-time RT-PCR during berry development. BMC Plant Biol. 6:26-37.

Rigling, D., and Prospero, S. 2018. Cryphonectria parasitica, the causal agent of chestnut blight: invasion history, population biology and disease control. Mol. Plant Pathol. 19:7-20.

Rott, M., Xiang, Y., Boyes, I., Belton, M., Saeed, H., Kesanakurti, P., Hayes, S., Lawrence, T., Birch, C., Bhagwat, B., and Rast, H. 2017. Application of Next Generation Sequencing for diagnostic testing of tree fruit viruses and viroids. Plant Dis. 101:14891499.

Shimada, S. 1962. Chestnut Yellows. PI. Prot. Tokyo, 16:253-254.

Smart, C. D., Schneider, B., Blomquist, C. L., Guerra, L. J., Harrison, N. A., Ahrens, U., Lorenz, K. H., Seemuller, E., and Kirkpatrick, B. C. 1996. Phytoplasma-specific PCR primers based on sequences of 16s-23s rRNA spacer region. Appl. Environ. Microbiol. 62:2988-2993.

Staginnus, C., Iskra-Caruana, M. L., Lockhart, B., Hohn, T., and Richert-Pöggeler, K. R. 2009. Suggestions for a nomenclature of endogenous pararetroviral sequences in plants. Arch. Virol. 154:1189-1193. 
473 Teycheney, P. Y., Geering, A. D. W., Dasgupta, I., Hull, R., Kreuze, J.F., Lockhart, B., Muller, E., 474 Olszewski, N., Pappu, H., Pooggin, M. M., Richert-Pöggeler, K. R., Schoelz, J. E.,Seal, S., Stavolone, 475 L., Umber, M. and ICTV Report Consortium. 2020. ICTV Virus Taxonomy Profile: Caulimoviridae. $476 \quad$ J. Gen. Virol. DOI 10.1099/jgv.0.001497

477 Thompson, J. D., Higgins, D. G., and Gibson, T. J. 1994. CLUSTALW: Improving the sensitivity of 478 progressive multiple sequence alignment through sequence weighting, position-specific gap, 479 penalties and weight matrix choice. Nucleic Acids Res. 22, 4673-4680.

480 Vettraino, M., Vannini, A., Flamini, L., Lagnese, R., Pizzichini, L., Talevi, S., and Fulbright, D. W. 2005. 481 A new transmissible symptomology on sweet chestnut in Italy. Acta Hortic. 693:547-550.

482 Villamor, D. E. V., Ho, T., Al Rwahnih, M., Martin, R. R., and Tzanetakis, I. E. 2019. High Throughput 483 Sequencing for plant virus detection and discovery. Phytopathology 109:716-725.

484 Wang, Y., Cheng, X., Wu, X., Wang, A., and Wu, X. 2014. Characterization of complete genome and 485 small RNA profile of pagoda yellow mosaic virus, a novel badnavirus in China. Virus Res. 188:103486108.

487 Zerbino, D. R., and Birney, E. 2008. Velvet: algorithms for de novo short read assembly using de 488 Bruijn graphs. Genome Res. 18:821-829. 
Armelle Marais

Phytopathology 22

489 TABLE 1. Percentage of identity between the ORF3 region encoding the Reverse Transcriptase -

490 Rnase $\mathrm{H}^{\mathrm{a}}$ of chestnut mosaic virus (ChMV) isolate FRIc1224A and the corresponding genomic regions

491 of the isolate ITumito39 and of the most closely related members of the genus Badnavirus

\begin{tabular}{lcc}
\hline Virus $^{\mathrm{b}}$ & Nucleotide identity (\%) & Amino acid identity (\%) \\
\hline ChMV ITumito39 & $91.9 \%$ & $97.8 \%$ \\
RYNV & $65.1 \%$ & $71.6 \%$ \\
GVBV & $64 \%$ & $68.9 \%$ \\
GVCV & $66.8 \%$ & $72.6 \%$ \\
BLRaV & $68.4 \%$ & $72.6 \%$ \\
WBV1 & $68.2 \%$ & $71.6 \%$ \\
PYMaV & $67.7 \%$ & $71.9 \%$
\end{tabular}

492 a This region is the one typical used for taxonomic discrimination in the family Caulimoviridae 493 (Teycheney et al. 2020)

494 b Acronyms used: RYNV, rubus yellow net virus; GVBV, gooseberry vein banding virus; GVCV, 495 grapevine vein-clearing virus; BLRaV, birch leafroll-associated virus; WBV1, wisteria badnavirus 1; 496 PYMaV, pagoda yellow mosaic-associated virus.

497

498 
499

500

Origin of the

sampled plants
Infected/total Infected/asympto plants (\%) matic plants (\%)
Infected/sympto Infected/plants matic plants (\%) with atypical

symptoms (\%)

\begin{tabular}{lcccc}
\hline France (overall) & $65 / 95(68.4 \%)$ & $23 / 47(48.9 \%)$ & $38 / 38(100 \%)$ & $4 / 10(40 \%)$ \\
Plot A & $13 / 23(56.5 \%)$ & $6 / 15(40 \%)$ & $6 / 6(100 \%)$ & $1 / 2(50 \%)$ \\
Plot E & $48 / 66(72.7 \%)$ & $15 / 28(53.6 \%)$ & $30 / 30(100 \%)$ & $3 / 8(37.5 \%)$ \\
Plot Port & $4 / 6(66.6 \%)$ & $2 / 4(50 \%)$ & $2 / 2(100 \%)$ & na ${ }^{b}$ \\
C. crenata & $5 / 6(83 \%)$ & $1 / 1(100 \%)$ & $4 / 4(100 \%)$ & $0 / 1$ \\
C. sativa & $30 / 43(70 \%)$ & $11 / 20(55 \%)$ & $18 / 18(100 \%)$ & $1 / 5(20 \%)$ \\
C. mollissima & $13 / 14(93 \%)$ & $1 / 2(50 \%)$ & $10 / 10(100 \%)$ & $2 / 2(100 \%)$ \\
Hybrid ${ }^{a}$ & $17 / 32(53.1 \%)$ & $10 / 24(41.6 \%)$ & $6 / 6(100 \%)$ & $1 / 2(50 \%)$ \\
Italy Castanea & $57 / 70(81.5 \%)$ & $5 / 10(50 \%)$ & $52 / 60(87 \%)$ & na ${ }^{b}$ \\
sativa & & & \\
\hline a Interspecific hybrids between C. crenata, C. mollisima and C. sativa \\
b not applicable
\end{tabular}

503

\section{CAPTIONS FOR FIGURES}

Fig. 1. Symptoms of chestnut mosaic disease on various hosts. (A) Isolate LC1224H: Red oak (Quercus rubra) graft-inoculated with a diseased source; (B) Isolate FRIc1224A: 'Maraval' Ca 74 graft-inoculated with LC1224H; (C) Isolate ITumito39: symptomatic leaves from cv Marrone grafted onto Castanea sativa;

(D) non-inoculated

Q. rubra; (E) non-inoculated 'Maraval' Ca 74; (F) Asymptomatic leaves from cv Marrone grafted onto $C$. sativa. 
Fig. 2: Schematic representation of the genomic organization of the chestnut mosaic virus. The tRNA binding site is indicated and defines the position 1 on the genome. The three open reading frames (ORFs) are shown as grey arrows, as well as their position in parentheses. Five conserved motifs are identified in the ORF3 polyprotein: MP, Viral movement protein (pfam01107); ZnF, Zinc finger (pfam00098); RVP, Retroviral aspartyl protease (pfam00077); RT, Reverse transcriptase (cd01647); RH, Ribonuclease H (cd09274)

Fig. 3. Phylogenetic tree reconstructed using the complete genome sequences of badnavirus members. Virus names as well as GenBank accession numbers are indicated. The tree was reconstructed using the neighbor-joining method, and randomized bootstrapping was performed to evaluate the statistical significance of branches (1,000 replicates). Bootstrap values above $70 \%$ are shown. The scale bar represents $5 \%$ nucleotide divergence between sequences. The groups as defined by Wang et al. (2014) are indicated. Chestnut mosaic virus isolates determined in this work are indicated by black triangles. Rice tungro bacilliform virus was used as outgroup.

Fig. 4. Unrooted neighbor-joining phylogenetic tree reconstructed from the alignment of concatenated nucleotide sequences related to chestnut mosaic virus detected by datamining of publicly available transcriptomic chestnut data. Randomized bootstrapping was performed to evaluate the statistical significance of branches (1,000 replicates). Bootstrap values above $70 \%$ are shown. The scale bar represents $10 \%$ nucleotide divergence between sequences.

Fig. 5. Detection of chestnut mosaic virus in various samples by PCR using primers pairs ChBad1466F/1800R (A) and Ch-Bad5860F/6109R (B). Lane 1: LC1224F; Lane 2: LC1224H; Lane 3: FRIc1224A; Lane 4: T32018; Lane 5: LCA552; Lane 6: LCA584; Lane 7: 'Maraval' Ca 74 non-inoculated plant; Lane 8: Quercus rubra non-inoculated plant; Lane 9: no template; L: molecular weight marker. are listed in Table S1. 
540

541 Supplementary Fig. S1. Phylogenetic tree reconstructed using the ORF3-deduced amino acid 542 sequences of badnavirus members. Virus names as well as GenBank accession numbers are 543 indicated. The tree was reconstructed using the neighbor-joining method, and randomized 544 bootstrapping was performed to evaluate the statistical significance of branches (1,000 replicates). 545 Bootstrap values above $70 \%$ are shown. The scale bar represents $10 \%$ amino acid divergence 546 between sequences. Chestnut mosaic virus isolates determined in this work are indicated by black triangles. Rice tungro bacilliform virus was used as outgroup.

Supplementary Fig. S2. Leaves of the sample 20893. (A) rootstock leaves (Castanea sativa); (B) cultivar leaves

Supplemental Fig. S3. Unrooted neighbor-joining phylogenetic trees reconstructed from the alignment of nucleotide sequences of the PCR fragments targeted partial RT-RnaseH domain (A) and partial MP domain (B) obtained from a range of chestnut mosaic virus isolates (listed in Table S1). Randomized bootstrapping was performed to evaluate the statistical significance of branches (1,000 replicates). Bootstrap values above $70 \%$ are shown. The scale bar represents $5 \%(A)$ or $10 \%$ (B) nucleotide divergence between sequences.

Supplemental Table S1. List of chestnut samples used in the present study together with relevant ChMV accession numbers

Supplemental Table S2. Primers used for genome circularity confirmation and for molecular detection of chestnut mosaic virus by PCR 
Armelle Marais

Phytopathology 26

565 Supplemental Table S3. Datamining of publicly available chestnut HTS data for chestnut mosaic

566 virus sequences 

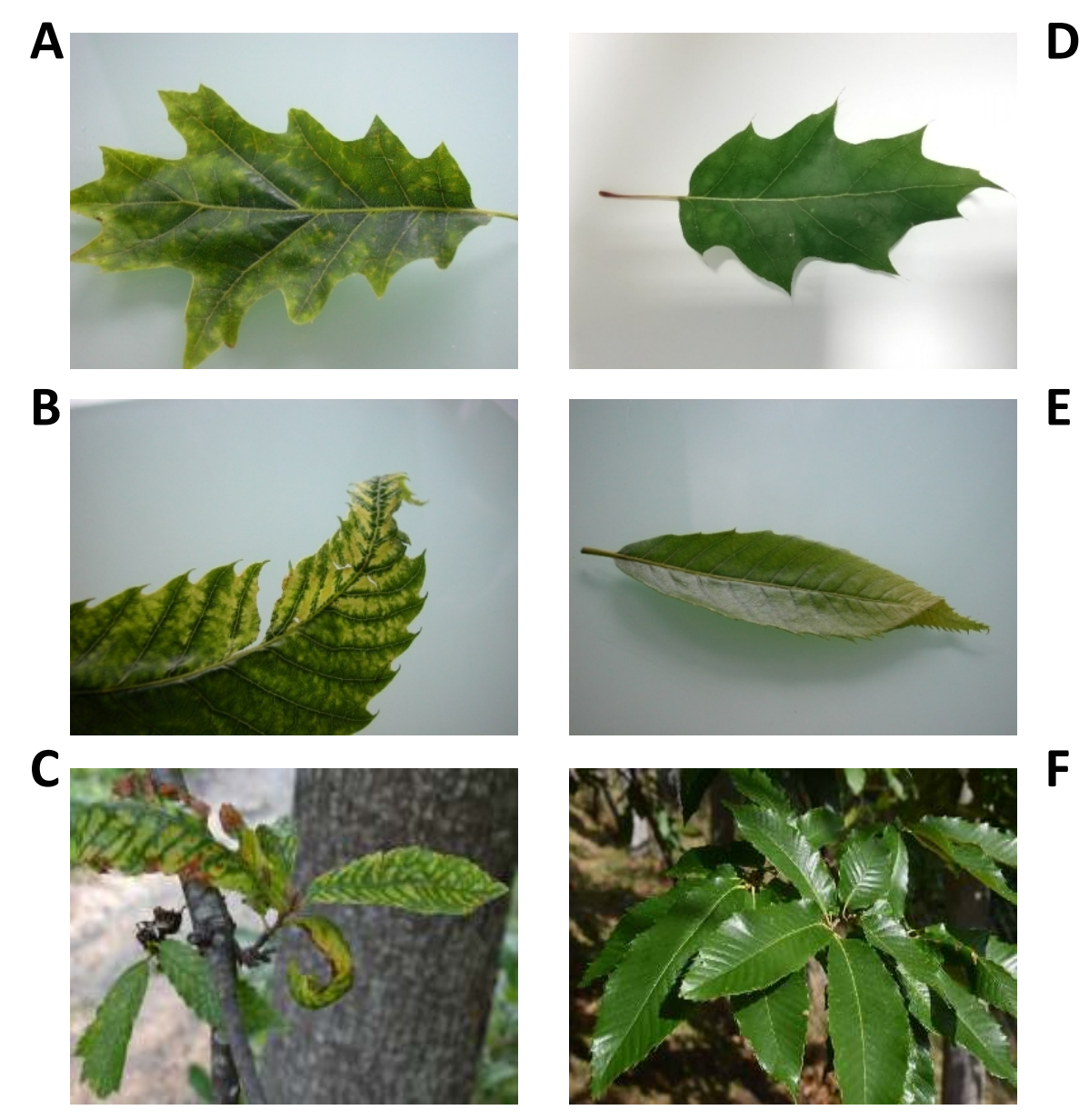

D

E

F 


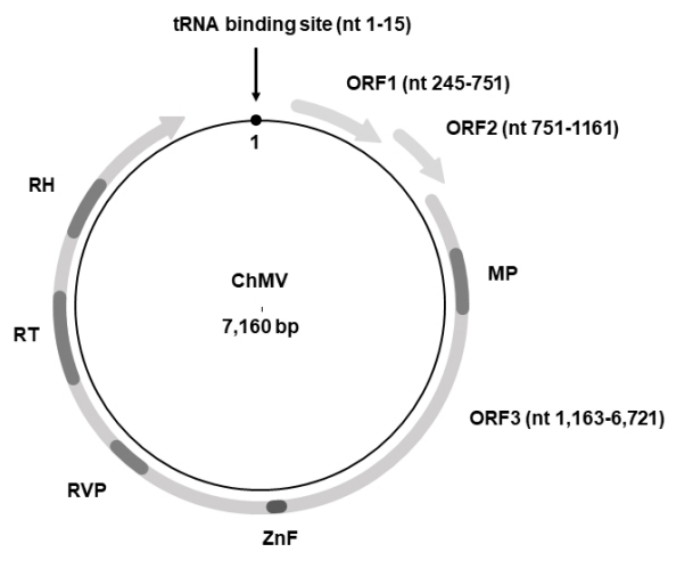

Fig. 2: Schematic representation of the genomic organization of the chestnut mosaic virus. The tRNA binding site is indicated and defines the position 1 on the genome. The three open reading frames (ORFs) are shown as grey arrows, as well as their position in parentheses. Five conserved motifs are identified in the ORF3 polyprotein: MP, Viral movement protein (pfam01107); ZnF, Zinc finger (pfam00098); RVP, Retroviral aspartyl protease (pfam00077); RT, Reverse transcriptase (cd01647); RH, Ribonuclease H (cd09274) 


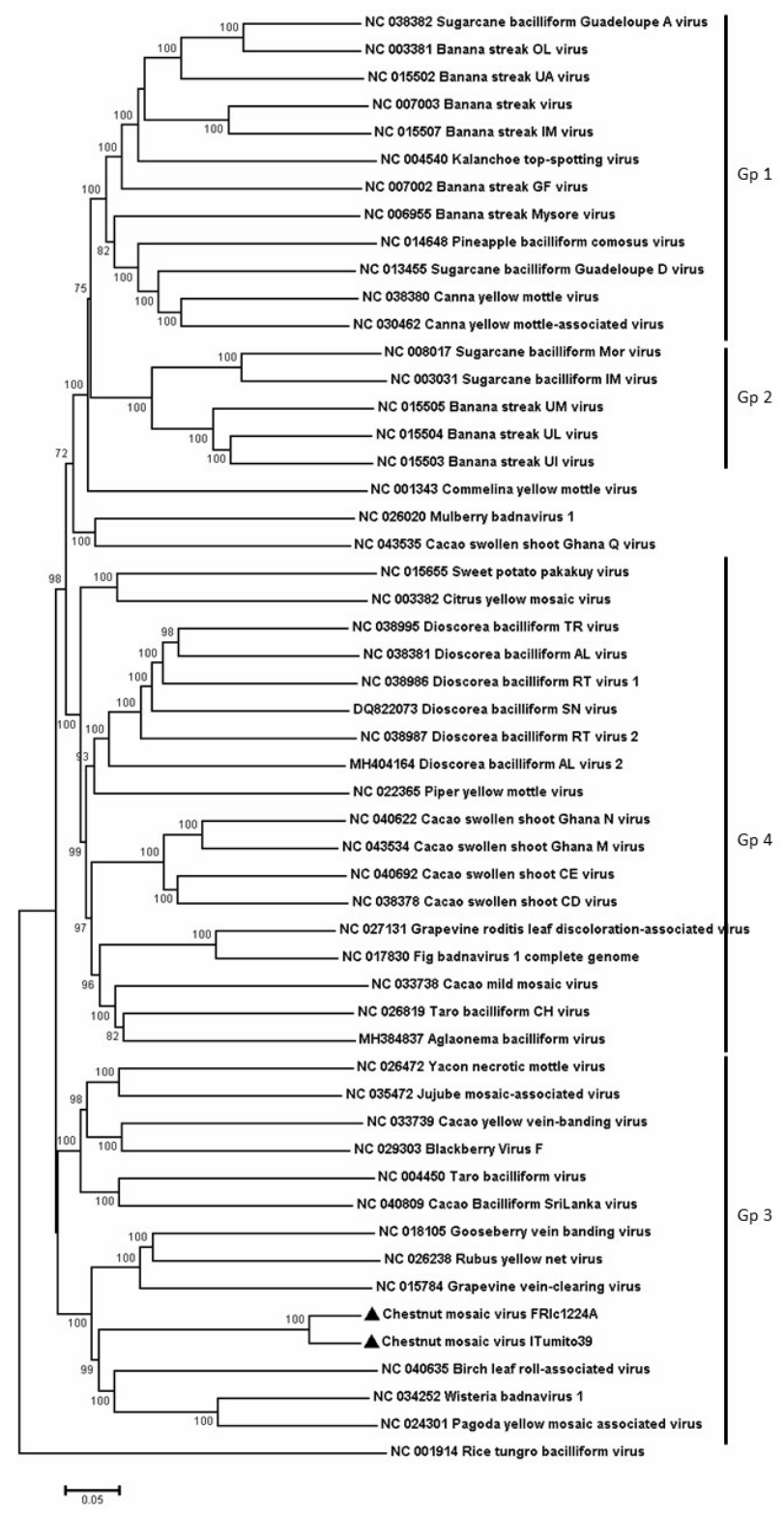

Fig. 3. Phylogenetic tree reconstructed using the complete genome sequences of badnavirus members. Virus names as well as GenBank accession numbers are indicated. The tree was reconstructed using the neighborjoining method, and randomized bootstrapping was performed to evaluate the statistical significance of branches (1,000 replicates). Bootstrap values above $70 \%$ are shown. The scale bar represents $5 \%$ nucleotide divergence between sequences. The groups as defined by Wang et al. (2014) are indicated. Chestnut mosaic virus isolates determined in this work are indicated by black triangles. Rice tungro bacilliform virus was used as outgroup. 


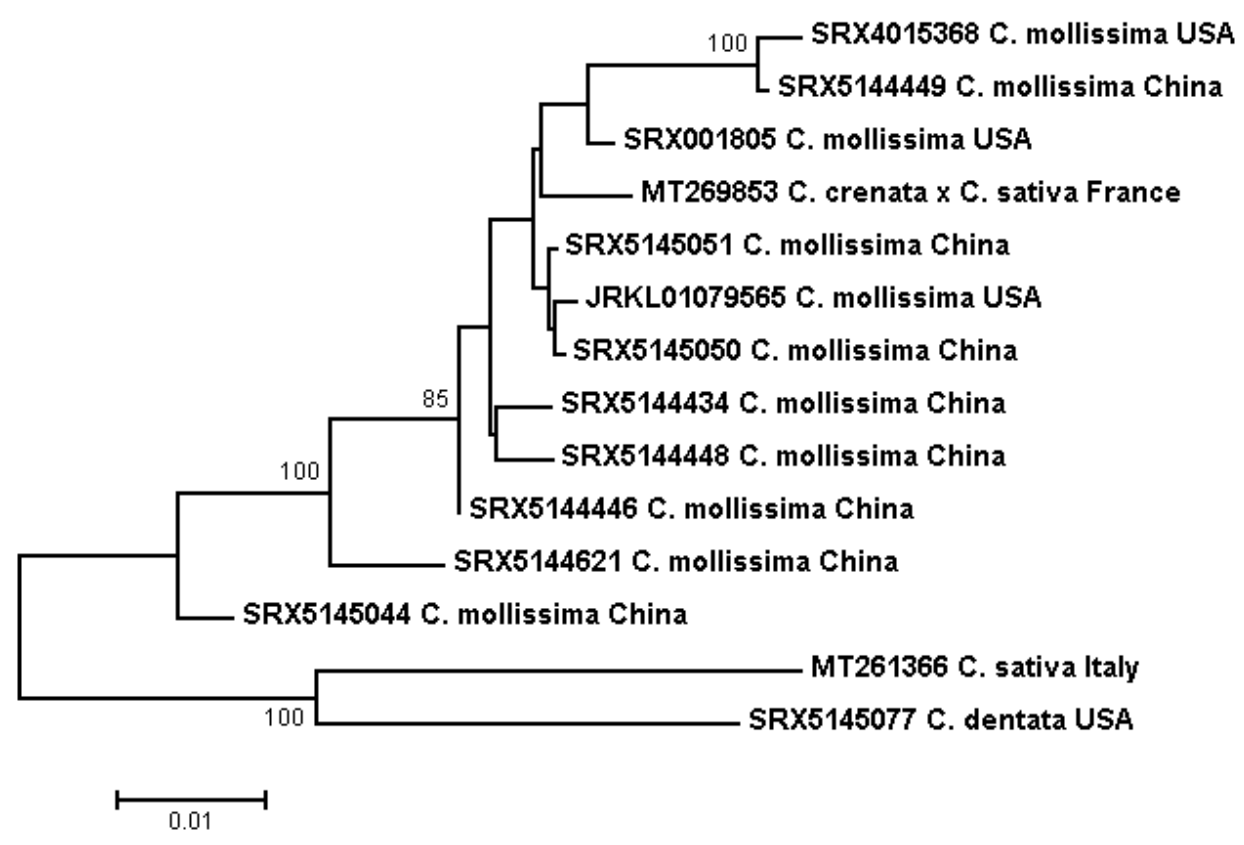


A

$\begin{array}{llllllllll}1 & 2 & 3 & 4 & 5 & 6 & 7 & 8 & 9 & \text { L }\end{array}$

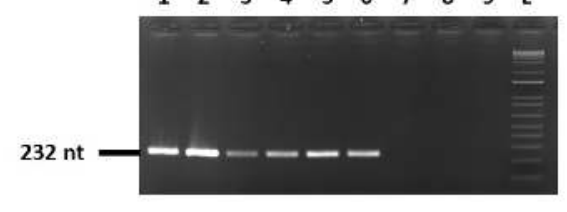

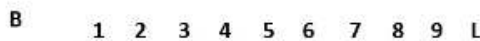

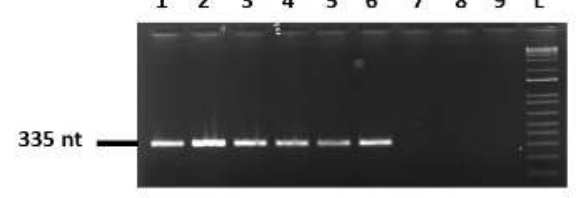

Fig. 5. Detection of chestnut mosaic virus in various samples by PCR using primers pairs ChBad1466F/1800R (A) and Ch-Bad5860F/6109R (B). Lane 1: LC1224F; Lane 2: LC1224H; Lane 3: FRIc1224A; Lane 4: T32018; Lane 5: LCA552; Lane 6: LCA584; Lane 7: 'Maraval' Ca 74 non-inoculated plant; Lane 8: Quercus rubra non-inoculated plant; Lane 9: no template; L: molecular weight marker. Horizontal bars on the left of the figure indicate the size of the amplification products. The isolates are listed in Table S1.

$338 \times 190 \mathrm{~mm}(96 \times 96 \mathrm{DPI})$ 
Fig. S1

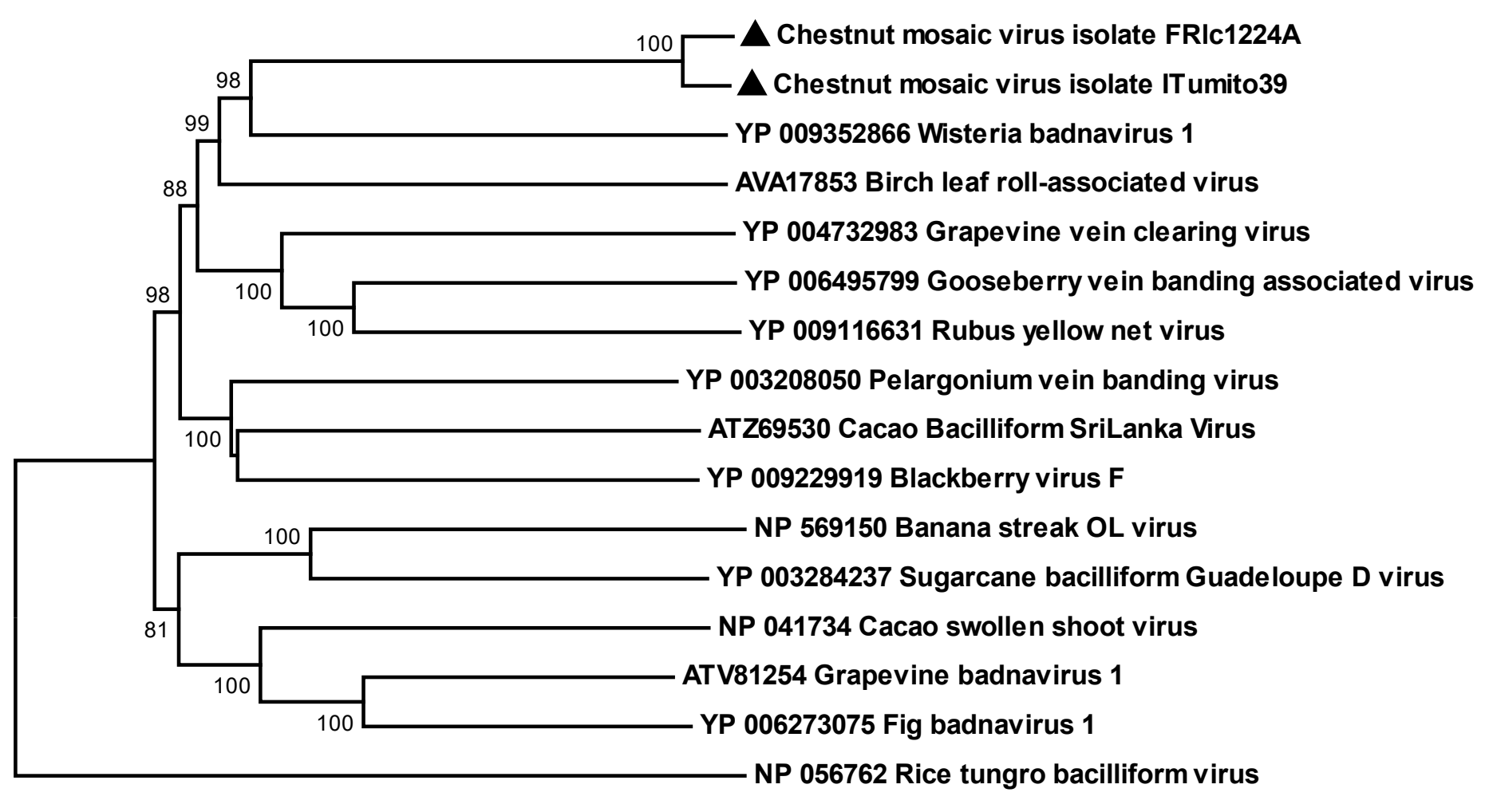




$$
\text { } \overline{\underline{\underline{\underline{z}}}}
$$


Fig. S3A

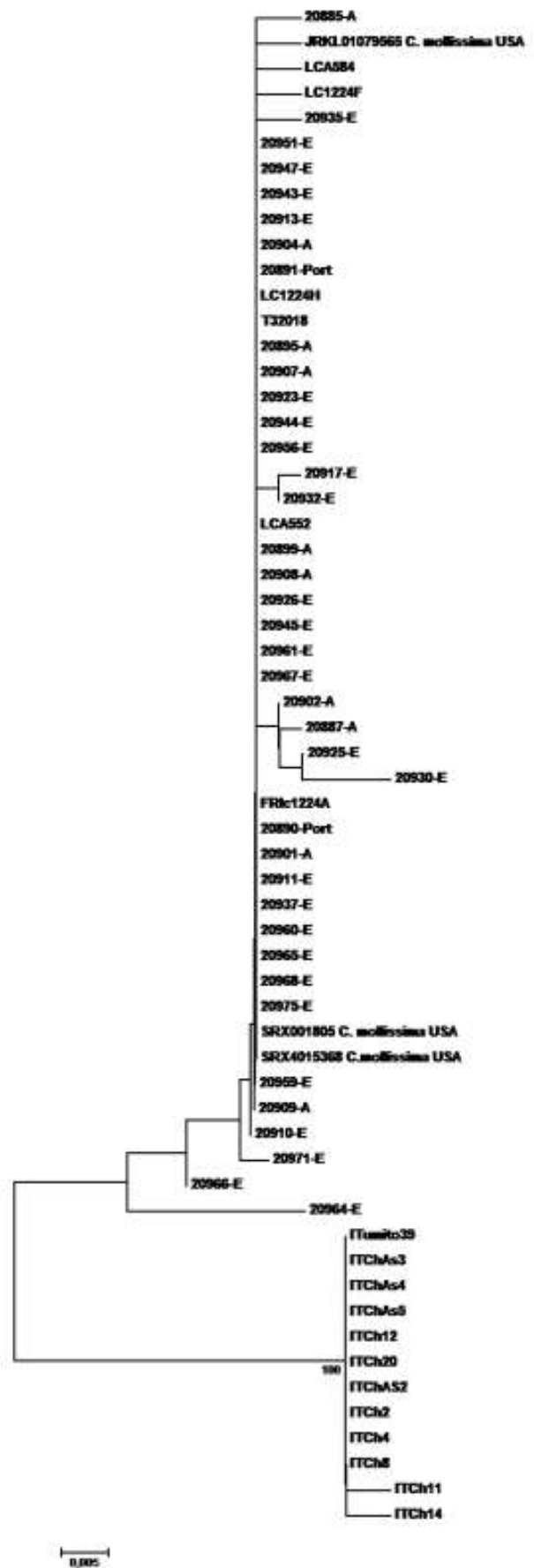


Page 35 of 43

Fig. S3B

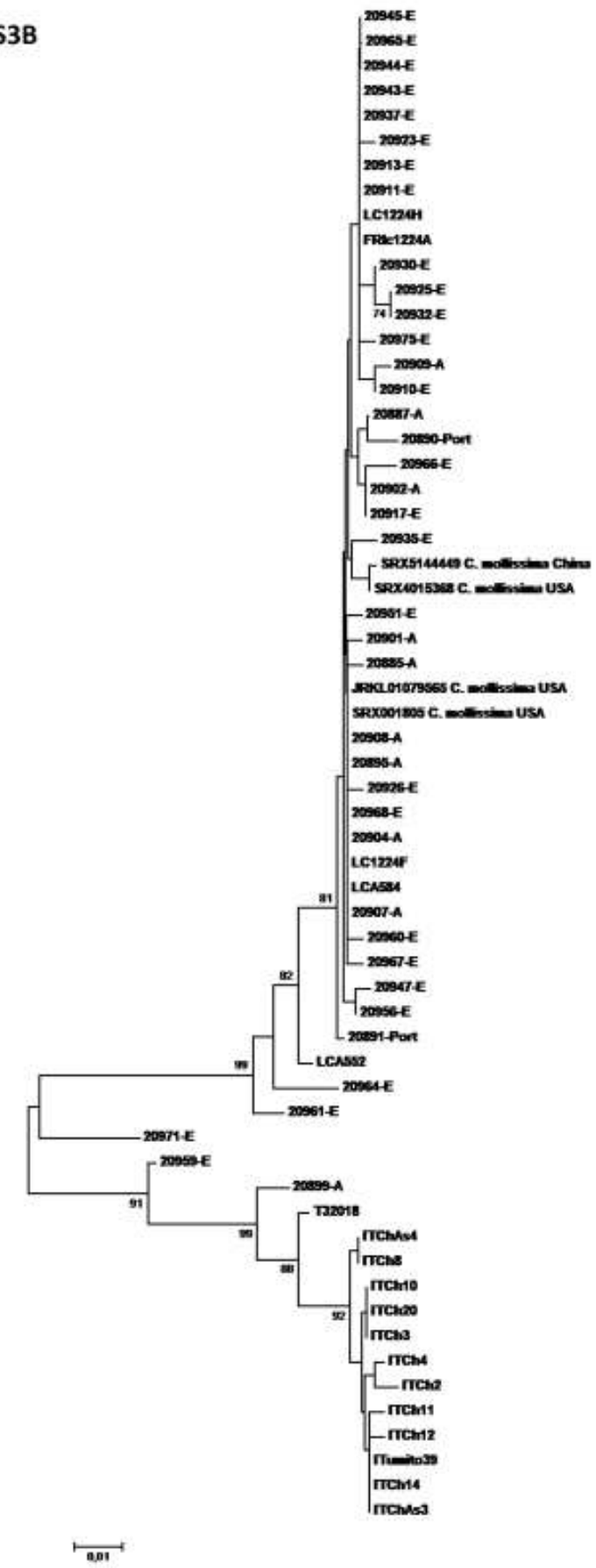




\begin{tabular}{|c|c|c|c|c|c|c|c|c|}
\hline Isolate ID a & $\begin{array}{l}\text { Chestnut } \\
\text { Accession } \\
\text { ID }\end{array}$ & $\begin{array}{l}\text { Chestnut } \\
\text { Accession } \\
\text { name }\end{array}$ & Species $^{b}$ & Rootstock & Country & Plot $^{c}$ & $\begin{array}{l}\text { Accession } \\
\text { numbers }^{d}\end{array}$ & Use ${ }^{e}$ \\
\hline 20885 & $\begin{array}{l}\mathrm{Ca04x} \\
\mathrm{CaO} 3\end{array}$ & - & C. crenata & Not graft & France & $A$ & $\begin{array}{l}\text { МT339547; } \\
\text { MT339503 }\end{array}$ & Incidence \\
\hline 20887 & Ca 715 & 'Merle' & C. sativa & G1. Ca15 & France & A & $\begin{array}{l}\text { MT339548; } \\
\text { MT339504 }\end{array}$ & Incidence \\
\hline 20890 & Ca 663 & 'Trigueira' & C. sativa & unknown & France & Port & $\begin{array}{l}\text { MT339549; } \\
\text { MT339505 }\end{array}$ & Incidence \\
\hline 20891 & Ca 664 & $\begin{array}{l}\text { 'Longal } \\
\text { Special' }\end{array}$ & C. sativa & Ca 74 & France & Port & $\begin{array}{l}\text { МT339550; } \\
\text { MT339506 }\end{array}$ & Incidence \\
\hline$\underline{20895}$ & Ca 43 & 'Vignols' & C. sativa $\times$ C. crenata & Ca 116 & France & A & $\begin{array}{l}\text { МT339551; } \\
\text { МT339507 }\end{array}$ & Incidence \\
\hline 20899 & Ca 599 & 'Ibuki' & C. crenata & G1.Ca 02 & France & A & $\begin{array}{l}\text { МT339552; } \\
\text { MT339508 }\end{array}$ & Incidence \\
\hline 20901 & Ca 598 & 'Rihei' & C. crenata $\times$ C. mollissima & G1. Ca102 & France & A & $\begin{array}{l}\text { МT339553; } \\
\text { МT339509 }\end{array}$ & Incidence \\
\hline 20902 & Ca 75 & 'Fertil' & C. mollissima & Ca 07 & France & A & $\begin{array}{l}\text { МT339554; } \\
\text { МT339510 }\end{array}$ & Incidence \\
\hline 20904 & $\begin{array}{l}\text { Tree- } \\
\text { A68Ks }^{i}\end{array}$ & - & C. mollissima & Not graft & France & A & $\begin{array}{l}\text { МT339555; } \\
\text { МT339511 }\end{array}$ & Incidence \\
\hline 20907 & Ca 118 & 'Marlhac' & C. sativa $\times$ C. crenata & Not graft & France & A & $\begin{array}{l}\text { МT339556; } \\
\text { МT339512 }\end{array}$ & Incidence \\
\hline 20908 & Ca 124 & 'Maridonne' & C. sativa $\times$ C. crenata & G1.Ca116 & France & A & $\begin{array}{l}\text { МT339557; } \\
\text { МT339513 }\end{array}$ & Incidence \\
\hline 20909 & Ca 125 & $\begin{array}{l}\text { 'Bouche de } \\
\text { Bétizac' }\end{array}$ & C. sativa $\times$ C. crenata & Ca 74 & France & A & $\begin{array}{l}\text { МT339558; } \\
\text { MT339514 }\end{array}$ & Incidence \\
\hline 20910 & Ca 860 & - & hybrid SC & unknown & France & $E$ & $\begin{array}{l}\text { MT339559; } \\
\text { MT339515 }\end{array}$ & Incidence \\
\hline 20911 & Ca 860 & - & hybrid SC & unknown & France & $\mathrm{E}$ & $\begin{array}{l}\text { МT339560; } \\
\text { MT339516 }\end{array}$ & Incidence \\
\hline 20913 & Ca $844^{i}$ & - & C. mollissima & Not graft & France & $E$ & $\begin{array}{l}\text { МT339561; } \\
\text { МT339517 }\end{array}$ & Incidence \\
\hline 20917 & Ca $837^{\mathrm{h}}$ & - & C. mollissima & Not graft & France & $\mathrm{E}$ & $\begin{array}{l}\text { МT339562; } \\
\text { МT339518 }\end{array}$ & Incidence \\
\hline 20923 & Ca $846^{h}$ & - & C. mollissima & Not graft & France & $\mathrm{E}$ & $\begin{array}{l}\text { МT339563; } \\
\text { МT339519 }\end{array}$ & Incidence \\
\hline 20925 & Ca 741 & 'Dauphine' & C. sativa & $\mathrm{Ca} 07$ & France & $\mathrm{E}$ & $\begin{array}{l}\text { MT339564; } \\
\text { MT339520 }\end{array}$ & Incidence \\
\hline 20926 & Ca 665 & 'Longal' & C. sativa & Ca 07 & France & $\mathrm{E}$ & $\begin{array}{l}\text { MT339565; } \\
\text { MT339521 }\end{array}$ & Incidence \\
\hline 20930 & Ca 860 & - & hybrid SC & unknown & France & $\mathrm{E}$ & $\begin{array}{l}\text { МT339566; } \\
\text { MT339522 }\end{array}$ & Incidence \\
\hline 20932 & Ca 564 & 'Ipharra 16' & C. crenata & Ca 07 & France & $\mathrm{E}$ & $\begin{array}{l}\text { МT339567; } \\
\text { МT339523 }\end{array}$ & Incidence \\
\hline 20935 & Ca 576 & 'Sardonne' & C. sativa & Ca 07 & France & $\mathrm{E}$ & $\begin{array}{l}\text { МT339568; } \\
\text { МT339524 }\end{array}$ & Incidence \\
\hline 20937 & Ca 138 & $\begin{array}{l}\text { 'Marron de } \\
\text { Redon' }\end{array}$ & C. sativa & Ca 07 & France & $\mathrm{E}$ & $\begin{array}{l}\text { МT339569; } \\
\text { MT339525 }\end{array}$ & Incidence \\
\hline 20943 & unknown & - & C. sativa & Ca 74 & France & $\mathrm{E}$ & $\begin{array}{l}\text { МT339570; } \\
\text { МT339526 }\end{array}$ & Incidence \\
\hline 20944 & Ca 520 & 'Montagne' & C. sativa & Ca 07 & France & $\mathrm{E}$ & $\begin{array}{l}\text { МT339571; } \\
\text { MT339527 }\end{array}$ & Incidence \\
\hline 20945 & Сa 106 & $\begin{array}{l}\text { 'Marron } \\
\text { Comballe' }\end{array}$ & C. sativa & Са 07 & France & $E$ & $\begin{array}{l}\text { МT339572; } \\
\text { МT339528 }\end{array}$ & Incidence \\
\hline
\end{tabular}




\begin{tabular}{|c|c|c|c|c|c|c|c|c|}
\hline 20947 & Ca 111 & $\begin{array}{l}\text { 'Marron de } \\
\text { Lyon' }\end{array}$ & C. sativa & Ca 07 & France & $\mathrm{E}$ & $\begin{array}{l}\text { MT339573; } \\
\text { MT339529 }\end{array}$ & Incidence \\
\hline 20951 & Ca 126 & - & C. sativa $\times$ C. crenata & Ca 07 & France & $E$ & $\begin{array}{l}\text { MT339574; } \\
\text { MT339530 }\end{array}$ & Incidence \\
\hline 20956 & Ca 105 & 'Sardonne' & C. sativa & Ca 07 & France & $\mathrm{E}$ & $\begin{array}{l}\text { MT339575; } \\
\text { МT339531 }\end{array}$ & Incidence \\
\hline 20959 & Ca 03 & - & C. crenata & Ca 74 & France & $E$ & $\begin{array}{l}\text { MT339576; } \\
\text { MT339532 }\end{array}$ & Incidence \\
\hline 20960 & Ca 127 & - & $\begin{array}{l}\text { (C. crenata } \times \text { C. sativa) } \times C \text {. } \\
\text { mollisima }\end{array}$ & Ca 07 & France & $\mathrm{E}$ & $\begin{array}{l}\text { MT339577; } \\
\text { MT339533 }\end{array}$ & Incidence \\
\hline 20961 & Ca 127 & - & $\begin{array}{l}\text { (C. crenata } \times \text { C. sativa) } \times C \text {. } \\
\text { mollisima }\end{array}$ & Ca 07 & France & $\mathrm{E}$ & $\begin{array}{l}\text { MT339578; } \\
\text { MT339534 }\end{array}$ & Incidence \\
\hline 20964 & Ca 112 & 'Bournette' & C. crenata $\times$ C. sativa & Сa 07 & France & $\mathrm{E}$ & $\begin{array}{l}\text { MT339579; } \\
\text { MT339535 }\end{array}$ & Incidence \\
\hline 20965 & Ca 501 & - & C. sativa & Ca 07 & France & $\mathrm{E}$ & $\begin{array}{l}\text { MT339580; } \\
\text { MT339536 }\end{array}$ & Incidence \\
\hline 20966 & Ca 501 & - & C. sativa & Сa 07 & France & $E$ & $\begin{array}{l}\text { МT339581; } \\
\text { MT339537 }\end{array}$ & Incidence \\
\hline 20967 & Ca 665 & 'Longal' & C. sativa & Ca 07 & France & $E$ & $\begin{array}{l}\text { МT339582; } \\
\text { МT339538 }\end{array}$ & Incidence \\
\hline 20968 & Ca 48 & $\begin{array}{l}\text { 'Précoce } \\
\text { Migoule' }\end{array}$ & (C. crenata $\times$ C. sativa) & Ca 07 & France & $E$ & $\begin{array}{l}\text { МT339583; } \\
\text { MT339539 }\end{array}$ & Incidence \\
\hline 20971 & Ca 151 & $\begin{array}{l}\text { 'Bouche } \\
\text { Rouge' }\end{array}$ & C. sativa & Ca 07 & France & $E$ & $\begin{array}{l}\text { МT339584; } \\
\text { МT339540 }\end{array}$ & Incidence \\
\hline 20975 & unknown & - & C. sativa $\times$ C. crenata & Ca 07 & France & $\mathrm{E}$ & $\begin{array}{l}\text { МT339585; } \\
\text { MT339541 }\end{array}$ & Incidence \\
\hline 20889 & unknown & - & C. sativa & unknown & France & Port & na & Incidence \\
\hline 20893 & Ca 106 & $\begin{array}{l}\text { 'Marron } \\
\text { Comballe' }\end{array}$ & C. sativa & unknown & France & Port & na & Incidence \\
\hline 20898 & Ca 105 & 'Sardonne' & C. sativa & G1. Ca394 & France & $A$ & na & Incidence \\
\hline 20900 & Ca 501 & - & C. sativa & G1.Ca486 & France & A & na & Incidence \\
\hline 20903 & Ca744 & 'Quing Zha' & C. mollissima & G1.Moll & France & $A$ & na & Incidence \\
\hline 20912 & $\mathrm{Ca} 845^{\mathrm{h}}$ & - & C. mollissima & Not graft & France & $E$ & na & Incidence \\
\hline 20914 & $\mathrm{Ca} 843^{\mathrm{h}}$ & - & C. mollissima & Not graft & France & $E$ & na & Incidence \\
\hline 20915 & $\mathrm{Ca} 842^{\mathrm{h}}$ & - & C. mollissima & Not graft & France & $E$ & na & Incidence \\
\hline$\underline{20918}$ & Ca $838^{h}$ & - & C. mollissima & Not graft & France & $E$ & na & Incidence \\
\hline$\underline{20919}$ & Ca $839^{h}$ & - & C. mollissima & Not graft & France & $E$ & na & Incidence \\
\hline 20920 & Ca $840^{h}$ & - & C. mollissima & Not graft & France & $E$ & na & Incidence \\
\hline 20921 & Ca $841^{\mathrm{h}}$ & - & C. mollissima & Not graft & France & $E$ & na & Incidence \\
\hline 20922 & Ca 74 & 'Maraval' & C. crenata $\times$ C. sativa & Not graft & France & $E$ & na & Incidence \\
\hline 20924 & Ca 825 & $\begin{array}{l}\text { 'Précoce de } \\
\text { Besse' }\end{array}$ & C. sativa & Ca 07 & France & $\mathrm{E}$ & na & Incidence \\
\hline 20940 & Сa 393 & $\begin{array}{l}\text { 'Marron de } \\
\text { Chevanceaux' }\end{array}$ & C. sativa & Ca 07 & France & $\mathrm{E}$ & na & Incidence \\
\hline 20941 & Ca 460 & - & $\begin{array}{l}\text { (C. crenata } \times \text { C. sativa }) \times(C . \\
\text { crenata } \times \text { C. sativa })\end{array}$ & Ca 74 & France & $\mathrm{E}$ & na & Incidence \\
\hline 29942 & Ca 511 & $\begin{array}{l}\text { 'Marrone di } \\
\text { Chiusa Pesio' }\end{array}$ & C. sativa & Ca 74 & France & $E$ & na & Incidence \\
\hline 20948 & Ca 116 & - & C. sativa $\times$ C. crenata & Ca 74 & France & $E$ & na & Incidence \\
\hline 20949 & Ca 135 & $\begin{array}{l}\text { 'Précoce des } \\
\text { Vans' }\end{array}$ & C. sativa & Ca 74 & France & $\mathrm{E}$ & na & Incidence \\
\hline 20952 & Ca 521 & - & C. crenata & Ca 07 & France & $E$ & na & Incidence \\
\hline
\end{tabular}




\begin{tabular}{|c|c|c|c|c|c|c|c|c|}
\hline 20955 & Ca 399 & 'Comballe' & C. sativa & Ca 07 & France & $\mathrm{E}$ & na & Incidence \\
\hline 20962 & Ca 639 & - & C. sativa & Ca 07 & France & $E$ & na & Incidence \\
\hline 20963 & Ca 730 & $\begin{array}{l}\text { 'Sauvage } \\
\text { Marron' }\end{array}$ & C. sativa & Ca 07 & France & $E$ & na & Incidence \\
\hline 20969 & Ca 381 & - & C. sativa & Ca 07 & France & $\mathrm{E}$ & na & Incidence \\
\hline 20970 & Ca 381 & - & C. sativa & Ca 07 & France & $\mathrm{E}$ & na & Incidence \\
\hline 20972 & Ca 151 & $\begin{array}{l}\text { 'Bouche } \\
\text { Rouge' }\end{array}$ & C. sativa & Ca 07 & France & $\mathrm{E}$ & na & Incidence \\
\hline FRIC1224A & Ca 74 & 'Maraval' & C. crenata $\times$ C. sativa & na & France & Ctifl & $\begin{array}{l}\text { MT269853 } \\
\text { (complete } \\
\text { genome) }\end{array}$ & HTS \\
\hline LC1224H & na & na & Q. rubra & na & France & Ctifl & $\begin{array}{l}\text { МТ339586; } \\
\text { МT339542 }\end{array}$ & CRA \\
\hline T32018 & Ca 74 & Maraval & C. crenata $\times$ C. sativa & na & France & Ctifl & $\begin{array}{l}\text { МT339587; } \\
\text { МT339543 }\end{array}$ & CRA \\
\hline LCA552 & Ca 74 & Maraval & C. sativa & na & France & Ctifl & $\begin{array}{l}\text { МТ339588; } \\
\text { МT339544 }\end{array}$ & CRA \\
\hline LCA584 & Ca 74 & Maraval & C. sativa & na & France & Ctifl & $\begin{array}{l}\text { МT339589; } \\
\text { МT339545 }\end{array}$ & CRA \\
\hline LC1224F & Ca 74 & Maraval & C. crenata $\times$ C. sativa & na & France & Ctifl & $\begin{array}{l}\text { МТ339590; } \\
\text { МT339546 }\end{array}$ & CRA \\
\hline ITUmito39 & unknown & Marrone & C. sativa & na & Italy & I & $\begin{array}{l}\text { MT261366 } \\
\text { (complete } \\
\text { genome) }\end{array}$ & HTS \\
\hline ITCh2 & unknown & Marrone & C. sativa & na & Italy & 1 & $\begin{array}{l}\text { МT270674; } \\
\text { МT270683 }\end{array}$ & Incidence \\
\hline ITCh3 & unknown & Marrone & C. sativa & na & Italy & 1 & MT27066 ${ }^{f}$ & Incidence \\
\hline ITCh4 & unknown & Marrone & C. sativa & na & Italy & 1 & $\begin{array}{l}\text { МT270668; } \\
\text { МT270684 }\end{array}$ & Incidence \\
\hline ITCh8 & unknown & Marrone & C. sativa & na & Italy & I & MT270685 & Incidence \\
\hline ITCh10 & unknown & Marrone & C. sativa & na & Italy & I & $\begin{array}{l}\text { МT270669; } \\
\text { MT270678 }\end{array}$ & Incidence \\
\hline ITCh11 & unknown & Marrone & C. sativa & na & Italy & 1 & $\begin{array}{l}\text { MT270664; } \\
\text { MT270679 }\end{array}$ & Incidence \\
\hline ITCh12 & unknown & Marrone & C. sativa & na & Italy & I & $\begin{array}{l}\text { MT270665; } \\
\text { МT270680 }\end{array}$ & Incidence \\
\hline ITCh14 & unknown & Marrone & C. sativa & na & Italy & 1 & $\begin{array}{l}\text { MT270666; } \\
\text { MT270681 }\end{array}$ & Incidence \\
\hline ITCh20 & unknown & Marrone & C. sativa & na & Italy & 1 & $\begin{array}{l}\text { МT270670; } \\
\text { МT270675 }\end{array}$ & Incidence \\
\hline ITChAs3 & unknown & Marrone & C. sativa & na & Italy & 1 & $\begin{array}{l}\text { МT270671; } \\
\text { MT270676 }\end{array}$ & Incidence \\
\hline ITChAs4 & unknown & Marrone & C. sativa & na & Italy & 1 & MT270672 ${ }^{f}$ & Incidence \\
\hline ITChAs5 & unknown & Marrone & C. sativa & na & Italy & I & MT270677 g & Incidence \\
\hline ITChAs8 & unknown & Marrone & C. sativa & na & Italy & 1 & $\begin{array}{l}\text { MT270673; } \\
\text { MT270682 }\end{array}$ & Incidence \\
\hline ITChAs9 & unknown & Marrone & C. sativa & na & Italy & I & na & Incidence \\
\hline ITCh1 & unknown & Marrone & C. sativa & na & Italy & I & na & Incidence \\
\hline ITCh5 & unknown & Marrone & C. sativa & na & Italy & 1 & na & Incidence \\
\hline ITCh6 & unknown & Marrone & C. sativa & na & Italy & I & na & Incidence \\
\hline ITCh7 & unknown & Marrone & C. sativa & na & Italy & 1 & na & Incidence \\
\hline ITCh9 & unknown & Marrone & C. sativa & na & Italy & I & na & Incidence \\
\hline ITCh13 & unknown & Marrone & C. sativa & na & Italy & 1 & na & Incidence \\
\hline ITCh14 & unknown & Marrone & C. sativa & na & Italy & 1 & na & Incidence \\
\hline ITCh15 & unknown & Marrone & C. sativa & na & Italy & 1 & na & Incidence \\
\hline ITCh20 & unknown & Marrone & C. sativa & na & Italy & 1 & na & Incidence \\
\hline ITCh21 & unknown & Marrone & C. sativa & na & Italy & 1 & na & Incidence \\
\hline
\end{tabular}


Page 39 of 43

\begin{tabular}{|c|c|c|c|c|c|c|c|c|}
\hline ITCh22 & unknown & Marrone & C. sativa & na & Italy & I & na & Incidence \\
\hline ITCh23 & unknown & Marrone & C. sativa & na & Italy & 1 & na & Incidence \\
\hline ITCh24 & unknown & Marrone & C. sativa & na & Italy & 1 & na & Incidence \\
\hline ITCh25 & unknown & Marrone & C. sativa & na & Italy & I & na & Incidence \\
\hline ITCh27 & unknown & Marrone & C. sativa & na & Italy & 1 & na & Incidence \\
\hline ITCh28 & unknown & Marrone & C. sativa & na & Italy & 1 & na & Incidence \\
\hline ITCh29 & unknown & Marrone & C. sativa & na & Italy & I & na & Incidence \\
\hline ITCh30 & unknown & Marrone & C. sativa & na & Italy & 1 & na & Incidence \\
\hline ITCh31 & unknown & Marrone & C. sativa & na & Italy & I & na & Incidence \\
\hline ITCh32 & unknown & Marrone & C. sativa & na & Italy & 1 & na & Incidence \\
\hline ITCh33 & unknown & Marrone & C. sativa & na & Italy & 1 & na & Incidence \\
\hline ITCh35 & unknown & Marrone & C. sativa & na & Italy & 1 & na & Incidence \\
\hline ITCh36 & unknown & Marrone & C. sativa & na & Italy & 1 & na & Incidence \\
\hline ITCh37 & unknown & Marrone & C. sativa & na & Italy & 1 & na & Incidence \\
\hline ITCh38 & unknown & Marrone & C. sativa & na & Italy & I & na & Incidence \\
\hline ITCh39 & unknown & Marrone & C. sativa & na & Italy & 1 & na & Incidence \\
\hline ITCh41 & unknown & Marrone & C. sativa & na & Italy & 1 & na & Incidence \\
\hline ITCh42 & unknown & Marrone & C. sativa & na & Italy & 1 & na & Incidence \\
\hline ITCh43 & unknown & Marrone & C. sativa & na & Italy & I & na & Incidence \\
\hline ITCh44 & unknown & Marrone & C. sativa & na & Italy & I & na & Incidence \\
\hline ITCh46 & unknown & Marrone & C. sativa & na & Italy & 1 & na & Incidence \\
\hline ITCh47 & unknown & Marrone & C. sativa & na & Italy & 1 & na & Incidence \\
\hline ITCh48 & unknown & Marrone & C. sativa & na & Italy & 1 & na & Incidence \\
\hline ITCh49 & unknown & Marrone & C. sativa & na & Italy & 1 & na & Incidence \\
\hline ITCh50 & unknown & Marrone & C. sativa & na & Italy & I & na & Incidence \\
\hline ITCh51 & unknown & Marrone & C. sativa & na & Italy & 1 & na & Incidence \\
\hline ITCh52 & unknown & Marrone & C. sativa & na & Italy & I & na & Incidence \\
\hline ITCh54 & unknown & Marrone & C. sativa & na & Italy & 1 & na & Incidence \\
\hline ITCh55 & unknown & Marrone & C. sativa & na & Italy & 1 & na & Incidence \\
\hline ITCh56 & unknown & Marrone & C. sativa & na & Italy & 1 & na & Incidence \\
\hline ITCh58 & unknown & Marrone & C. sativa & na & Italy & 1 & na & Incidence \\
\hline ITCh59 & unknown & Marrone & C. sativa & na & Italy & I & na & Incidence \\
\hline ITCh60 & unknown & Marrone & C. sativa & na & Italy & 1 & na & Incidence \\
\hline
\end{tabular}

3 asolates from asymptomatic trees are indicated in bold; isolates with doubtful symptoms are underlined; isolates from

4 asymptomatic cultivars with typical symptoms visible on rootstock regrowths are indicated in bold italic.

5 b; hybrid SC: hybrid between C. sativa and C. crenata, regardless the knowledge about which are the female and male parents.

$6 \quad$ c: Five plots have been sampled (A, Port, E, I, Ctifl)

7 : Accession numbers are relative to the sequences obtained with both PCR detection assays (Ch-Bad-1466F/Ch-Bad-1800R and

8 Ch-Bad-5860F/Ch-Bad-6109R)

9 e: Isolates were included either in the HTS analysis, or in the incidence analysis, or in the causal relationship analysis (CRA)

10 f: Only the fragment amplified with Ch-Bad-1466F/Ch-Bad-1800R was sequenced

11 g: Only the fragment amplified with Ch-Bad-5860F/Ch-Bad-6109R was sequenced

12 h 'Mengshankui' (C. mollissima cultivar) seedling

13 'C. mollissima seedling 
Supplemental TABLE S2. Primers used for genome circularity confirmation and for molecular detection of chestnut mosaic virus by PCR

\begin{tabular}{|c|c|c|c|c|}
\hline Primer & $\begin{array}{l}\text { Nucleotide } \\
\left.\text { sequence ( } 5^{\prime} \text { to } 3^{\prime}\right)\end{array}$ & $\begin{array}{c}\text { Genome } \\
\text { coordinates }\end{array}$ & Amplicon size & Isolates detected \\
\hline Ch-Bad-6976F & $\begin{array}{l}\text { CCCGAGCCATTTAC } \\
\text { ACTTCACAAC }\end{array}$ & $6,976-6,999$ & $436 \mathrm{nt}$ & FRIc1224A \\
\hline Ch-Bad-252R & $\begin{array}{l}\text { TСАСТСАТСТАССТС } \\
\text { АСАСGСТC }\end{array}$ & $252-230$ & & \\
\hline Ch-Bad-6481F & $\begin{array}{l}\text { GAAATTGAATTGGA } \\
\text { AGGAAGA }\end{array}$ & $6,481-6,501$ & $1,007 \mathrm{nt}$ & ITumito39 \\
\hline Ch-Bad-325R & $\begin{array}{l}\text { TCAGATCAGCAAAC } \\
\text { TCGAAC }\end{array}$ & $344-325-$ & & \\
\hline Ch-Bad-1466F & $\begin{array}{l}\text { TATCAGCACTACAG } \\
\text { TGAACAACC } \\
\text { GTCATGACGCAAAC } \\
\text { TTGGAA }\end{array}$ & $\begin{array}{l}1,466-1,488 \\
1,800-1,781\end{array}$ & $335 \mathrm{nt}$ & +2 \\
\hline Ch-Bad-5860F & $\begin{array}{l}\text { AGTATGTAAATGG } \\
\text { GCACCGTTC } \\
\text { GTTGATCCATCGCA } \\
\text { CTCTTG }\end{array}$ & $5,857-5,878$ & $232 \mathrm{nt}$ & 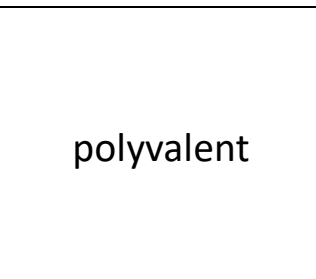 \\
\hline
\end{tabular}


1 Supplemental TABLE S3. Datamining of publicly available chestnut HTS data for chestnut mosaic

2 virus sequences

\begin{tabular}{|c|c|c|c|c|c|c|}
\hline $\begin{array}{l}\text { Type of } \\
\text { data }^{a}\end{array}$ & Dataset & $\begin{array}{l}\text { Castanea } \\
\text { species/cultivar }\end{array}$ & Country & $\begin{array}{l}\text { Length of } \\
\text { assembled } \\
\text { sequence } \\
\text { (nt) }\end{array}$ & $\begin{array}{l}\% \text { mapped } \\
\text { reads }^{b}\end{array}$ & $\begin{array}{l}\% \text { nt identity } \\
\text { with FRIc1224A }\end{array}$ \\
\hline EST & G0917001 & $\begin{array}{l}\text { C. mollissima, BX3, } \\
\text { clone Vanuxum }\end{array}$ & USA & 436 & na & $99 \%$ \\
\hline WGA & JRKL01079565 & $\begin{array}{l}\text { C. mollissima, cv } \\
\text { Vanuxem }\end{array}$ & USA & $\begin{array}{l}7,164 \text { (full } \\
\text { lenght) }\end{array}$ & na & $99 \%$ \\
\hline RNA-Seq & SRX4015368 & C. mollissima & USA & $\begin{array}{l}7,161 \text { (full } \\
\text { lenght) }\end{array}$ & $0.004 \%$ & $97.4 \%$ \\
\hline RNA-Seq & SRX001805 & $\begin{array}{l}\text { C. mollissima, cv } \\
\text { Vanuxem }\end{array}$ & USA & $\begin{array}{l}5,889 \\
\text { (scaffold) }\end{array}$ & $0.04 \%$ & $95-100 \%$ \\
\hline GBS & SRX5144434 & C. mollissima & China & $\begin{array}{l}5,933 \\
\text { (scaffold) }\end{array}$ & $0.06 \%$ & 98.7\% (average) \\
\hline GSB & SRX5144449 & $\begin{array}{l}\text { C. mollissima, } \\
\text { clone Vanuxem }\end{array}$ & China & $\begin{array}{l}\text { 6,396 } \\
\text { (scaffold) }\end{array}$ & $0.04 \%$ & 97.5\% (average) \\
\hline GBS & SRX5145051 & $\begin{array}{l}\text { C. mollissima, cv } \\
\text { Vanuxem }\end{array}$ & China & $\begin{array}{l}5,873 \\
\text { (scaffold) }\end{array}$ & $0.02 \%$ & 99\% (average) \\
\hline GBS & SRX5145050 & C. mollissima & China & $\begin{array}{l}6,680 \\
\text { (scaffold) }\end{array}$ & $0.01 \%$ & 99\% (average) \\
\hline GBS & SRX51445044 & C. mollissima & China & $\begin{array}{l}6,183 \\
\text { (scaffold) }\end{array}$ & $0.01 \%$ & 97.4\% (average) \\
\hline GBS & SRX51444621 & C. mollissima & China & $\begin{array}{l}5,875 \\
\text { (scaffold) }\end{array}$ & $0.02 \%$ & $95.6 \%$ (average) \\
\hline GBS & SRX51444448 & C. mollissima & China & $\begin{array}{l}2,948 \\
\text { (scaffold) }\end{array}$ & $0.04 \%$ & 99\% (average) \\
\hline GBS & SRX51444446 & C. mollissima & China & $\begin{array}{l}5,873 \\
\text { (scaffold) }\end{array}$ & $0.04 \%$ & 99\% (average) \\
\hline
\end{tabular}




\begin{tabular}{|c|c|c|c|c|c|c|}
\hline GBS & SRX5825095 & C. dentata & USA & $\begin{array}{l}1,857 \\
\text { (scaffold) }\end{array}$ & $0.0036 \%$ & 89.2\% (average) \\
\hline GBS & SRX5145077 & C. dentata & USA & $\begin{array}{l}6,068 \\
\text { (scaffold) }\end{array}$ & $0.01 \%$ & 90.9\% (average) \\
\hline
\end{tabular}

$3 \quad{ }^{a}$ EST: expressed sequence tags; WGA: whole genome assembly; GBS: genotyping by sequencing

$4 \quad{ }^{b}$ Reads mapped to the genomic sequence of chestnut mosaic virus (French isolate) 
